\title{
Cereal Canopy Structure - Its Assessment and Use in Efficient Crop Management
}

\author{
Jan Křen, Tamara Dryšlová, Lubomír Neudert and Vojtěch Lukas
}

Additional information is available at the end of the chapter

http://dx.doi.org/10.5772/54528

\section{Introduction}

Cereals are economically the most important group of field crops. Detailed knowledge of stand structure and its development including interrelationships among individual plants in the stand (inter- and intra-plant competition) is a significant precondition for effective cropping treatments during the growing season, including agrochemicals application.

To attain higher effectiveness of crop management practices, extensive research on cereal stand structure was conducted in the 1980s and 1990s [1-6]. The stand state and structure reflect variability in soil conditions as well as cropping treatments. Results of individual methods used for modification of cropping treatments depend on a level of stand organization which is observed - a stand (plant population), plant, plant part (leaf, tiller) [7].

Stems and spikes are the most often assessed units of stand structure as for final and resulting expression of all factors affecting stand development. However, they are also reproductive units and basic units of an important cereal adaptation system - tillering [8]. Therefore, their appropriate assessment allows obtaining information of great biological and economic importance.

The chapter gives a review of evolution of approaches used for the assessment of cereal stand structure. Weaknesses and strengths of these approaches are discussed.

\subsection{Approaches based on dividing of cereal yield and growth analysis}

The growth in biology is usually described by observing temporal development of average measurement values. Similarly, for analyses of yield formation a number of formed and reduced yield elements per unit area (tillers, reproductive organs and grains) is observed and their average values are determined. 
The assessment of cereal stands and yield formation is usually based on the classical concept as reported by Heuser [9] and later on by a number of other authors who divided grain yield into spike number per unit area, grain number per spike and grain weight (1000-grain weight) - Figure 1 .

At present, this concept based on the plant number and numbers of formed and reduced tillers per stand unit area prevails in both applied research and practice. It uses advantages of plant as well as stand description on the basis of changes in the tiller number when no destructive analyses and higher labour intensity are needed. Recently, however, the concept has been often criticized because it does not provide enough precise quantification of differences in stands. Hunt [10] drew an attention to changes in the number and size of plant parts (modules) during plant growth and development. It is evident that the procedures based on the growth analysis are rather labour intensive; their simplification for practical use results in lower accuracy and does not allow to record spatial heterogeneity of the stand. Therefore, some authors expressed a need of available innovated criteria for stand assessment [11].

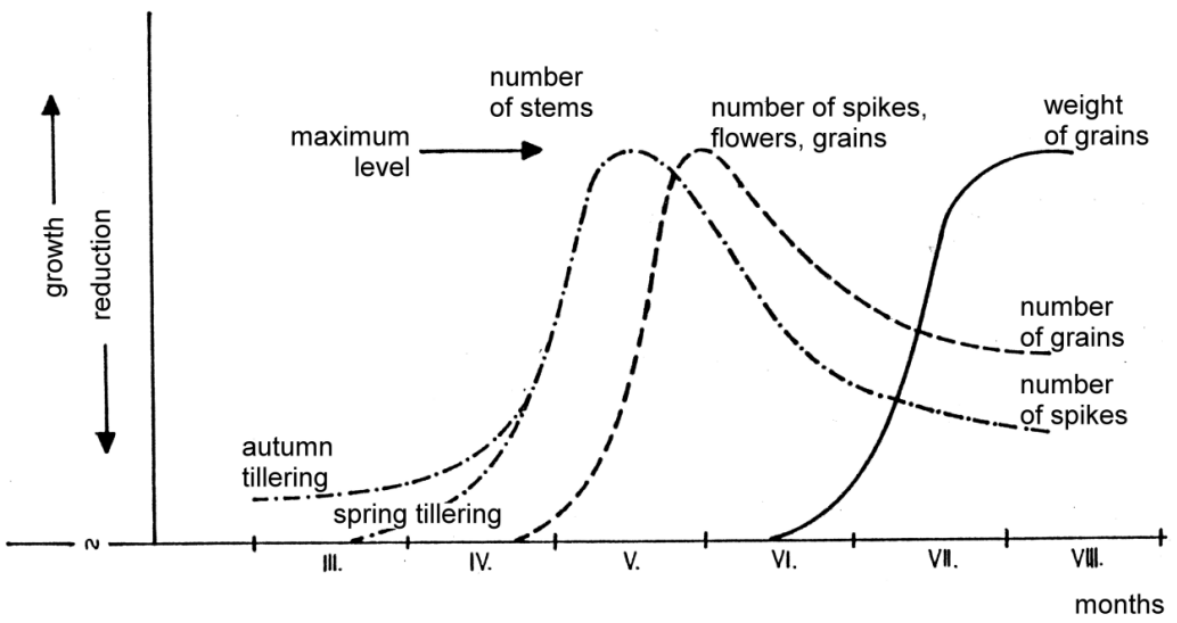

Figure 1. Schematic illustration of dynamics of yield elements formation and reduction in tillering cereals through the growing season [12]

\subsection{Plant modular growth and population concept of stem system of the stand}

Dividing of yield into individual yield components allowed cereal research and practice to get closer to so-called modular concept of plant and plant growth demographical analyses [13]. White [14] and Porter [15,16] report that plants can be studied as developing modular systems and their growth can be described similarly to processes of population type.

The growth and development of cereal plants consist of a number of growth and development stages of modules (leaves, shoots, stems and grains) that ovelap one another. Therefore, the growth and development of individual leaves and shoots are more 
determined than those of entire plant. The growth of entire plant does not stop unless the growth and development of the last module is finished, whereas the first formed modules finished their growth and development earlier. The size and properties of leaves and stems in the stand depend not only on their position on the plant, however, on the position of plants in the stand, i.e. on micro-conditions influencing the growth of individual plants [5]. Thus, in cereal stands the variability of site conditions is reflected in changes of inter- and intra-plant relationships, which is expressed by changes in variability of plant modular parts [6]. This concept enables to explain compensatory and autoregulatory processes in cereal stands by modification of both the number and size of plant parts. The stand structure can be described by density distribution (histogram, polygon) of their weight. For effective stand management of small-grain cereals it is important to assess the amount of biomass of productive stems per stand unit area or proportion of this "productive" biomass of the total amount of aboveground biomass.

\subsection{Autoregulation and compensation in the stand}

The cereal stand is usually interpreted as plants growing per unit area rather than individuals assembled in the population, and their interrelationships are most frequently measured as an average or average reaction [17]. However, some authors have earlier referred to relationships between the average and other statistical parameters - variance and skewness [18,19]. Křen [5,6] documented that these parameters enabled to evaluate intraplant relations.

The canopy closure can be established both through an increased number of stems and their increased size (weight). Stand productivity, as a result of compensatory and autoregulatory processes, depends on total productive stem weight per unit area and is limited by site productivity (carrying capacity that represents a summary of all sources which are available to plants in given space and time).

The identical yield of aboveground biomass can be obtained by lower plant density and a longer period of their growth or vice versa. This logically results in mutual compensation of plant density and size. In practice it means that at the formation of biomass amount corresponding to site carrying capacity self-thinning takes place during the further growth.

Changes in the number and size of shoots in cereal stand during the growing season are analogical to changes in natural plant populations and can be illustrated using frequency curves. A large potential number of shoots capable to reproduce are formed by tillering. This amount, however, reduces to a final spike number, which usually corresponds to $1 / 2$ to $1 / 4$ of the tiller number at the beginning of stem elongation ( $\mathrm{BBCH} 31$ ), by the period of anthesis (BBCH 61), when the organization of stand structure is finished.

The presented rules reveal that the stand structure is always a result of a response of the plant population to site conditions. Their good knowledge should be a basis for assessment of stand structure, which will enable more effective utilization of vegetation factors of the location, cropping treatments and properties of varieties. 
From this point of view, the development of root system is of a great significance. Strong root system is important for nutrients and water uptake, and leads directly to increasing the site carrying capacity. By the lower density of plants, they form more tillers and more roots. The rooted tillers exhibit better tolerance to unfavorable conditions. It leads to a general conclusion that to ensure high yield it is necessary to obtain as high number of productive stems and their biomass amount as possible by as the lowest plant number per unit area as possible. These are requirements for optimum development of plants in the stand and canopy closure. However, this general standpoint can be hardly implemented in practice since a large number of factors influencing the plant growth and development are impossible to control completely. Growers should take into consideration that the site productivity and duration of the growing season do not exhibit stable values that would enable to determine exactly sowing time, appropriate seeding rate and stand development during the vegetation. In particular cases, ability of knowing how to respond to the weather course in individual years using a way of stand establishment and consecutive cropping treatments is important. Thus, effective methods for the assessment of the stand during the growing season can be a valuable tool for farmers.

\subsection{Possibilities of innovations in stand structure assessment}

The stand structure depends on initial plant number, available sources and their change during the growing season. The value of obtained information should be adequate to consumed labour. In this respect, a sample size is of great importance. In general, it governs that with the increasing size and number of samples the exactness of results increases, however, labour intensity is also higher. The two problems (labour intensity as well as the value of obtained information) are to be solved, i.e. what information is provided by plant and stem analysis and how to use it.

Classical methods for the assessment of stand structure based on counting plants and stems (spikes) per unit area of the stand are labour consuming and interpretation of results is often difficult. They provide information on plant and stem numbers and/or their size (weight), however, they do not allow assessing the relationships in the stand (inter- and intra-plant competition).

Using a current level of knowledge and novel technologies could enable to make diagnostics of stand state and structure (to assess the amount of produced biomass and its structure) more effective. Based on data published over the last years [20-23], it can be assumed that spectral characteristics and area sensing of stands can be used for this purposes.

Based on the character of processes influencing the stand structure, the growing season of cereals was divided into the three parts:

1. vegetative, including the period from emergence till the end of tillering (BBCH 10-29),

2. generative, including the period of stem elongation and heading (BBCH 30-59),

3. reproductive, including anthesis, grain formation and maturation (BBCH 60-99). 


\section{Canopy structure development - problem statement}

\subsection{Vegetative period - from emergence till the end of tillering (BBCH 10-29)}

Vegetative period lasts from emergence to the end of tillering (BBCH 10-29), it is time limited by the transition to the double ridge stage. It includes the growth of the first leaves, formation of buds in leaf axils, and tillering (Figure 2). A number of code systems have been proposed for describing tillering pattern, of which the Rawson's system [24] has become the most universally accepted. Tillers are designated by letter $\mathrm{T}$ and the index which is determined by the order of leaves in whose axils the tillers emerge (Figure 3). Tiller buds in axils of the fifth and sixth leaves only sporadically grow more than 5-6 $\mathrm{mm}$, and in the axils of other leaves they remain small, clearly visible only after magnification. No buds can usually be observed in the axils of the eighth leaf and other leaves of the main stem [25].

\section{Tillering plant of wheat}

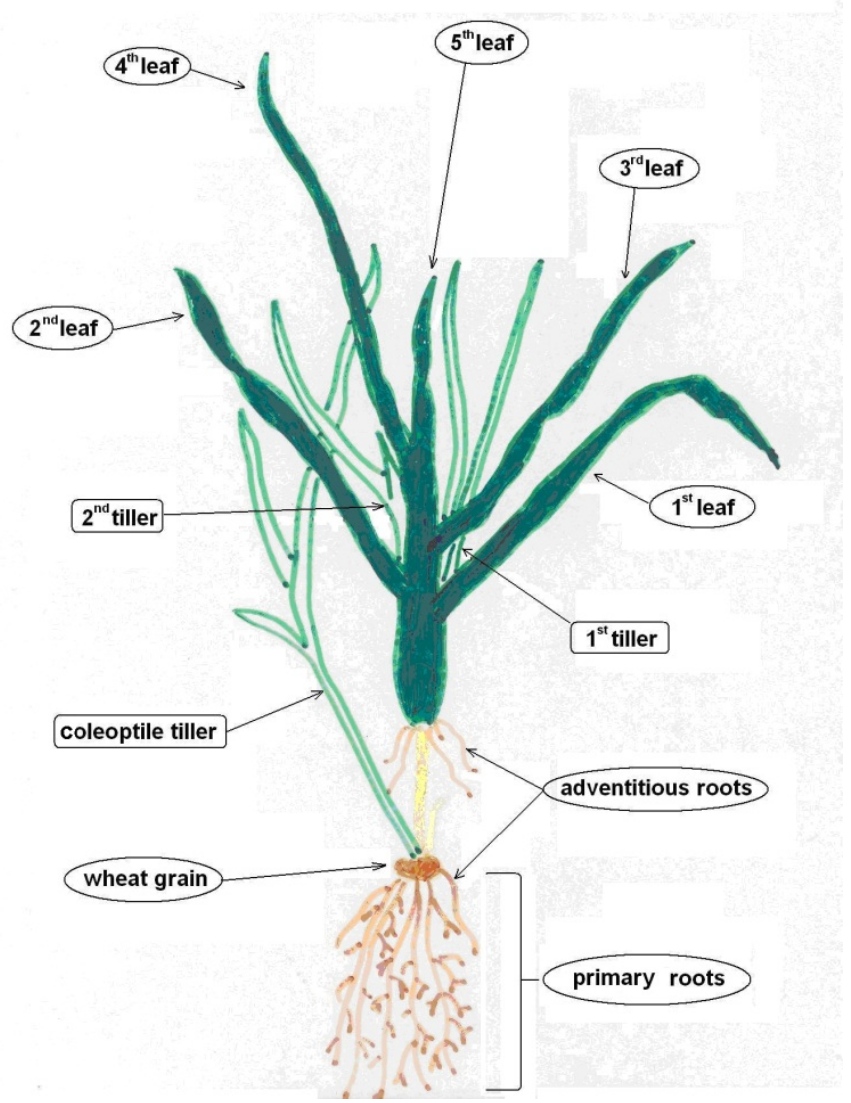

Figure 2. Illustration of tillering wheat plant [27] 
After emergence of seeds, number of plants per area unit is determined, i.e. space limitation of their growth, and pool of tillers for further selection is thus formed. By sampling it is possible to identify individual plants and their tillers in the stand. Weight distribution of plants is left-sided skewed. Plant variability indicates stand establishment quality (Graph 1). The values of the CV range between 30 and $60 \%$ in common stands [30].

Weight variability of tillers is the highest ( $\mathrm{CV}=50$ to $80 \%)$ in this period. It is caused by their gradual formation. The number of tillers per square meter in winter wheat and spring barley usually ranges from 1600 to 2500, in some cases exceeds 3000. Distribution of their weight is also strongly left-sided skewed, under favorable conditions is continuous and unimodal (Graph 1), which indicates good conditions for stem formation and stand structure development. Bimodal distribution indicates the effect of unfavorable conditions. Growth reduction occurs, tillers are smaller and apical dominance is strongly expressed. The segregating distribution therefore corresponds with the distribution of main shoots (Graph 1). As individual plants and tillers can be identified, the intra-plant relationships can directly be assessed, e.g. by regression analysis of tillers weight dependence on their sequence in the plants, however, it is very laborious.

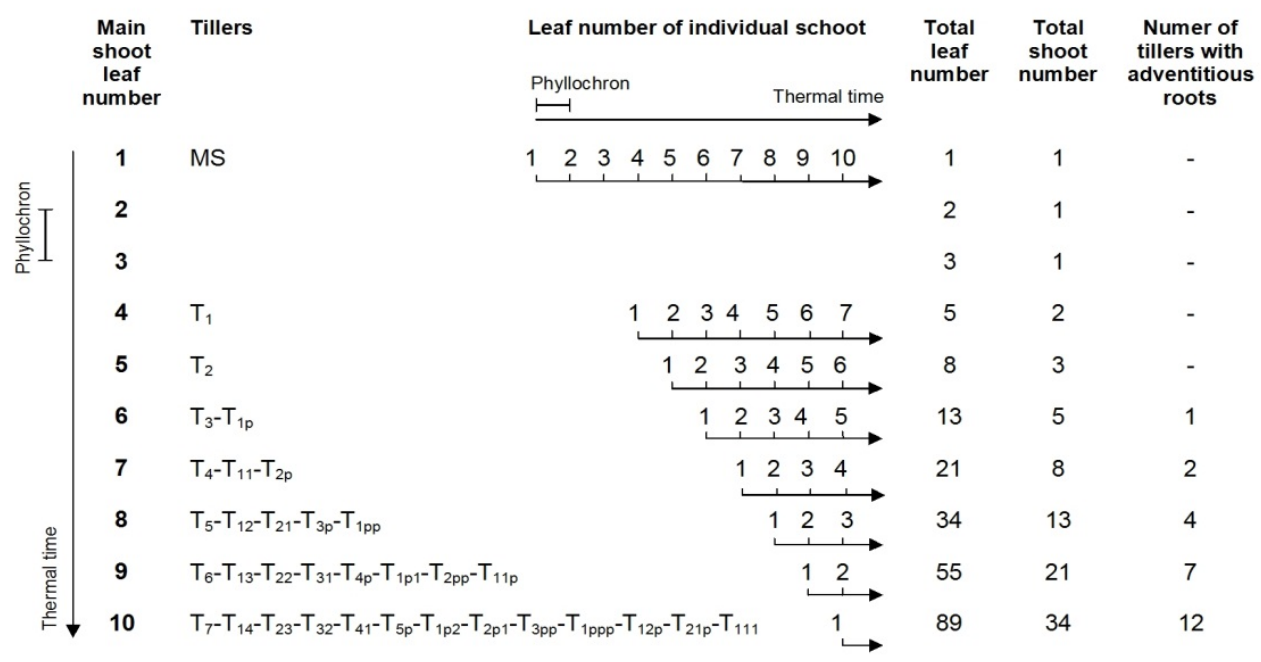

Figure 3. Schematic illustration of tillering wheat plant [28] - see Figure 2

Shoot growth is practically measurable since the first leaf emergence above ground (in the main shoot), and since bud emergence in leaf axils (in tillers). Tillers can also be formed, under certain circumstances, during the generative development (BBCH 30-59). Tillering at that time is undesirable with regard to efficient use of biomass for grain production as most of the late tillers are not fertile and those which are fertile increase grain variability. 

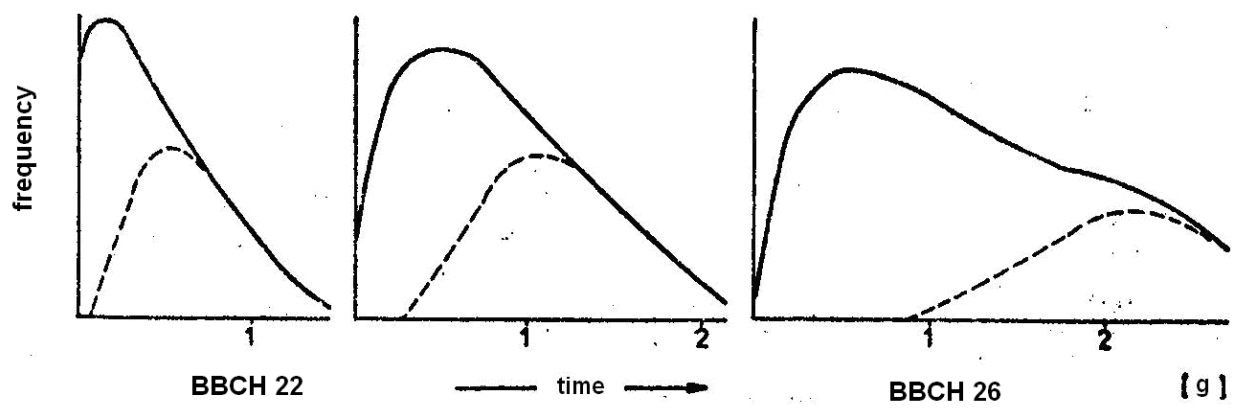

Graph 1. Schematic illustration of changes in density of tiller weight distribution of cereals during tillering [29]

Determination of plant and tiller density is in this stage important for assessment of the production potential of the stand and modification of cultivation measures, especially timing and dosing of $\mathrm{N}$ fertilizers, growth regulators and pesticides.

\subsection{Generative period - from stem elongation and heading ( $\mathrm{BBCH} 30-59)$}

Generative period is delimited by the stages of 'double ridge' (BBCH 30) and anthesis (BBCH 60) [3]. This period involves stages of stem elongation and heading, i.e. stages of an intensive growth and differentiation of tillers, their dying-off and formation of stems from the most robust ones; this is the result of selection resulting from competition among plants and tillers [8]. This results in a stabilization of numbers of productive stems per unit area at the end of canopy establishment. Depending on the variety and growing conditions, the number of productive stems per $\mathrm{m}^{2}$ ranges from 500 to 800 and from 700 to 1000 in stands of winter wheat and spring barley, respectively [30].

Individual plants can be credibly identified within the stand only till the beginning of heading [29]. This limits the evaluation of their variability and intraplant competition.

The distribution of the weight of tillers has two peaks and this is the reason why the variability evaluated by means of the variation coefficient does not give an exact picture of differentiation processes [29]. As shown in Graph 2, the distribution of non-productive (V) and productive tillers $(\mathrm{G})$ overlaps in the zone of local minimum. Critical weight of winter wheat tillers for transition to generative stage in analyses performed by [29] was about $2 \mathrm{~g}$. This illustration of stem differentiation shows stochastic character of the development of stand structure. This means that tillers belonging to weight categories corresponding with the local minimum may either be transformed into productive stems or die off; their fate is dependent on the course of weather and on the efficiency of applied growing measures. It is quite logical that with running time and intensifying differentiation the numbers of these tillers (and thus the possibility of a modification of stand productive density) decrease. 


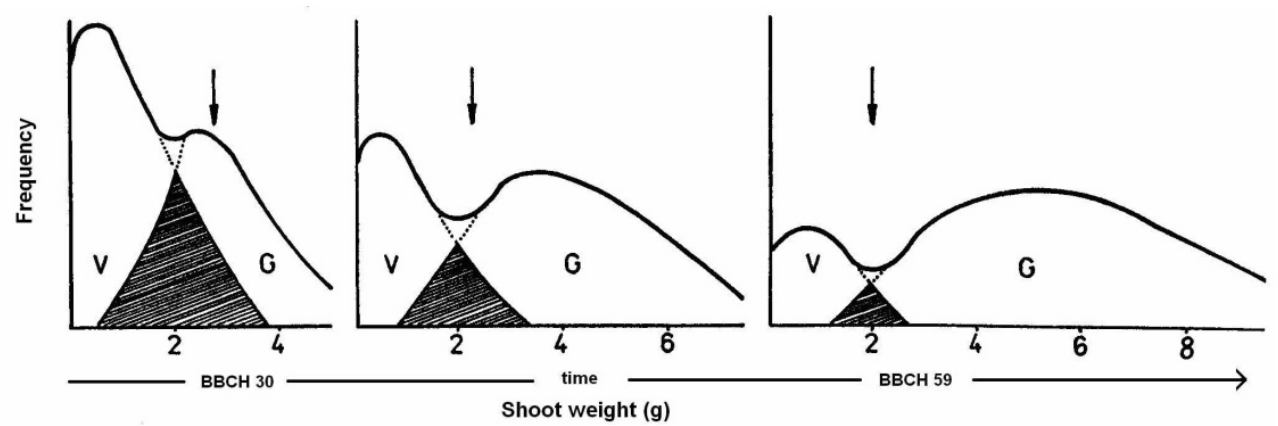

Graph 2. A schematic presentation of changes in the distribution of tiller weights during the period of generative development (BBCH 30-59). $\mathrm{V}$ - vegetative tillers, $\mathrm{G}$ - generative tillers (stems); the dark area represents tillers that can become, depending on availability of resources, either vegetative or generative [29].

An identification of productive and non-productive tillers is important for the estimation of the stand production potential and for the yield prognosis. This means that main objective should be the formation of a maximum possible number of productive tillers, i.e. of the maximum possible share of the so-called productive biomass in the total above-ground biomass. The development of the stand structure should be optimized in such a way that the produced biomass would maximally participate in the formation of grain yield.

\subsection{Reproductive period - including anthesis, grain formation and maturation (BBCH 60-99)}

The reproductive period includes pollination, grain filling and ripening (BBCH 61-91). Significant changes in the number of productive shoots occur only under very adverse conditions. However, their uniformity and variability can still be changed by a number of factors.

Individual plants cannot be identified in a stand therefore, the analyses carried out are limited to shoot variability and indirect assessment of intra-plant relationships. Weight distribution is at the beginning of this period bimodal with a pronounced right side representing the productive shoots, and increasing left side representing the rest of nonreduced unfertile tillers which usually die during grain filling (Graph 3). Weight distribution of the ears is in this period usually unimodal and nearly normal shape.

Shoot weight can be considered as basic information used for indirect estimation of the reproductive value and productivity of its ear. Rawson and Evans [31] reported narrow linear relationship $(r=0.94)$ between shoot weight at heading and a final number of grains in an ear. Our investigations also revealed highly significant linear correlation between shoot weight and number of embryos after flowering $(\mathrm{r}=0.91-0.94)$. Therefore, proportion of shoot weight per one embryo can be considered as a basic factor determining the number of grain embryos in ear [32]. Narrow correlations between the amount of the aboveground 
biomass formed until flowering $(\mathrm{BBCH} 60)$ and number of grains per area unit of a stand and also yield are reported by a number of authors [33-36].

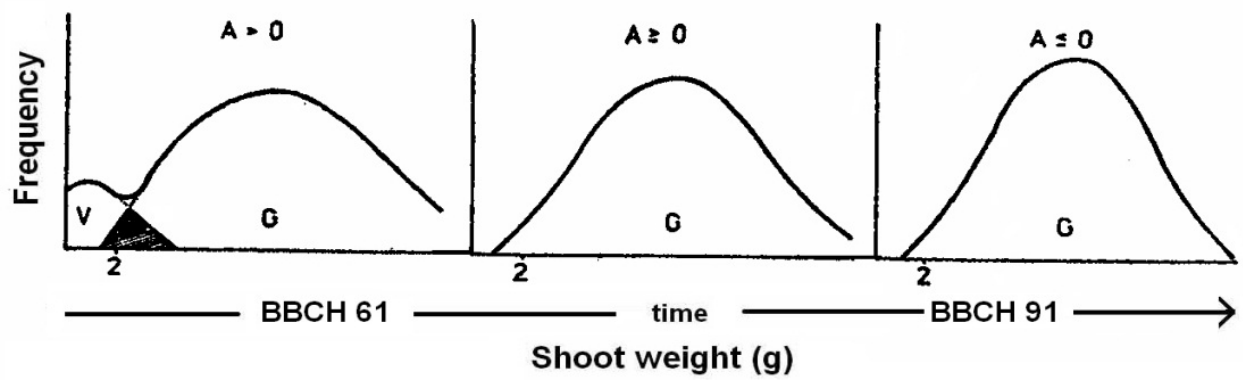

Graph 3. Schema of changes in tiller weight distribution during reproductive period (BBCH 60-91). Vvegetative tillers, $\mathrm{G}$ - generative tillers (stems), black area represents tillers which may be either vegetative or generative depending on source availability [29].

The amount of the biomass of productive tillers at the flowering (anthesis) can thus be used for prediction of the final stand yield. Duration of leaf area and redistribution of assimilates from stem to kernels is very important with respect to yield formation. Longer duration of the active green area supports higher yields. Many papers have been devoted to physiological processes of grain formation, most of which being based of the source $x$ sink approach. Great attention has been paid to supplying of embryos and filling grain with carbohydrates and nitrogen substances, and to the possibilities of better availability of these sources for grain filling by breeding and growing management [37-40].

If grains are comprehended as modules, similar rules of the population biology of plants can be applied to their formation as to tiller formation [41]. Weight distribution of grains can have different shapes (both bimodal and asymmetric unimodal) in dependence on stand structure and growth conditions. One of the most important quality parameters is grain uniformity. It has an effect on grain yield (proportion of grain above $2.5 \mathrm{~mm}$ mesh) and bulk density. Both parameters are important at processing of food wheat and malting barley. Variability in weight of grains is influenced by relationships on individual levels of the hierarchic structure of a cereal plant - tillering node and ear structure [42].

Only a limited number of cultivation measures have been performed during grain filling. Qualitative $\mathrm{N}$ rate is usually applied to winter wheat at heading. Later application of $\mathrm{N}$ fertilizers is exceptional. Sometimes, $\mathrm{N}$ is applied in a tank-mix of urea together with fungicides against ear diseases. Cultivation measures are, therefore, predominantly oriented to maintenance and performance of production potential of stand which has been formed at previous stages of growth and development. Following factors are important for yield formation and grain quality during the reproductive period:

- amount of the aboveground biomass formed and its structure,

- active green area and duration of its functionality,

- course of translocation and assimilate redistribution processes. 


\section{Experiments and methods}

\subsection{Characterization of locations and field experiments}

Evaluation of the canopy development of winter wheat and spring barley was carried out in small-plot field experiments established at two locations in Central and South Moravia (Table 1) within the period of three years (2005-2007). Experiments were conducted as contrast variants (Table 2) which took into account differences in the stand density and in the nutritional status of plants.

\begin{tabular}{|c|c|c|}
\hline \multirow{2}{*}{ Parameter } & \multicolumn{2}{|c|}{ Location } \\
\hline & Žabčice & Kroměříž \\
\hline Geographical location & $\begin{array}{l}49^{\circ} 01^{\prime} 20^{\prime \prime} \mathrm{N} \\
16^{\circ} 37^{\prime} 55^{\prime \prime} \mathrm{E}\end{array}$ & $49^{\circ} 17^{\prime} 12^{\prime \prime} \mathrm{N} ; 17^{\circ} 21^{\prime} 50^{\prime \prime} \mathrm{E}$ \\
\hline Soil type & Gleyey fluvisol (FMG) & Luvic chernozem (CMl) \\
\hline Texture class & Clay loam & Silt loam \\
\hline Altitude $(\mathrm{m})$ & 177 & 235 \\
\hline Annual mean temperature $\left({ }^{\circ} \mathrm{C}\right)$ & 9.2 & 8.7 \\
\hline $\begin{array}{l}\text { Average annual sum of } \\
\text { precipitations (mm) }\end{array}$ & 480 & 599 \\
\hline
\end{tabular}

Table 1. Characteristics of experimental locations

\begin{tabular}{|c|c|c|c|c|c|c|}
\hline $\begin{array}{c}\text { Crop and } \\
\text { variety }\end{array}$ & $\begin{array}{l}\text { Fore- } \\
\text { crop }\end{array}$ & Variant & $\begin{array}{c}\text { Seeding rate } \\
\left(\text { seeds per } \mathrm{m}^{2}\right)\end{array}$ & 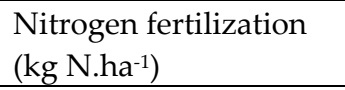 & Location & Year \\
\hline \multirow{4}{*}{$\begin{array}{l}\text { Winter } \\
\text { wheat, } \\
\text { variety } \\
\text { Cubus }\end{array}$} & \multirow{4}{*}{$\begin{array}{l}\text { Spring } \\
\text { barley }\end{array}$} & \multirow{2}{*}{ A } & \multirow{2}{*}{350} & \multirow{2}{*}{40 prior to sowing } & Žabčice & 2006,07 \\
\hline & & & & & Kroměříž & $2005,06,07$ \\
\hline & & \multirow[b]{2}{*}{ B } & \multirow[b]{2}{*}{500} & \multirow{2}{*}{$\begin{array}{l}40 \text { prior to sowing } \\
40 \text { during regeneration } \\
40 \text { at the beginning of } \\
\text { stem elongation }\end{array}$} & Žabčice & 2006,07 \\
\hline & & & & & Kroměříž & $2005,06,07$ \\
\hline \multirow{8}{*}{$\begin{array}{l}\text { Spring } \\
\text { barley, } \\
\text { variety } \\
\text { Malz }\end{array}$} & \multirow{8}{*}{ Maize } & \multirow{2}{*}{$C$} & \multirow{2}{*}{300} & \multirow{2}{*}{0} & Žabčice & 2005,07 \\
\hline & & & & & Kroměříž & $2005,06,07$ \\
\hline & & \multirow{2}{*}{$\mathrm{D}$} & \multirow{2}{*}{300} & $\begin{array}{l}60 / 05 \text { and } 50 / 07 \text { in the } \\
\text { stage of the } 3^{\text {rd }} \text { leaf }\end{array}$ & Žabčice & 2005,07 \\
\hline & & & & $\begin{array}{l}50 / 05,60 / 06 \text { and } 07 \\
\text { prior to sowing }\end{array}$ & Kroměříž & $2005,06,07$ \\
\hline & & \multirow{2}{*}{$\mathrm{E}$} & \multirow{2}{*}{500} & \multirow{2}{*}{0} & Žabčice & 2005,07 \\
\hline & & & & & Kroměříž & $2005,06,07$ \\
\hline & & & \multirow{2}{*}{500} & $\begin{array}{l}60 / 05 \text { and } 50 / 07 \text { in the } \\
\text { stage of the } 3^{\text {rd }} \text { leaf }\end{array}$ & Žabčice & 2005,07 \\
\hline & & & & $\begin{array}{l}50 / 05,60 / 06 \text { a } 07 \text { prior } \\
\text { to sowing }\end{array}$ & Kroměříž & $2005,06,07$ \\
\hline
\end{tabular}

Table 2. Characteristics of experimental variants 
Each experimental variant was established in six replications: three of them were harvested, two were used for sampling, which enabled to analyse the structure and nutritional status of the stand, and one served for multispectral imaging of a demarcated area of $0.25 \mathrm{~m}^{2}(0.5 \mathrm{mx}$ $0.5 \mathrm{~m}$ ) as well as for measuring of LAI by device SunScan System-SS1-R3-BF3 (manufacturer Delta-T Devices Ltd., U.K.). In sampling plots, squares of the size $0.25 \mathrm{~m}^{2}(0.5 \mathrm{~m} \times 0.5 \mathrm{~m})$ were also demarcated to obtain plants samples used for analyses of stand structure and samples of soil used for the estimation of the content of mineral nitrogen $\left(\mathrm{N}_{\min }\right)$ in depths of $0-30$ and $30-60 \mathrm{~cm}\left(\mathrm{~N}-\mathrm{NO}_{3}\right.$ and $\left.\mathrm{N}-\mathrm{NH}_{4}\right)$.

Multispectral images and samples of soil and plant material were obtained at the agronomically important developmental stages $\mathrm{BBCH} 25,31,37,55,65,87$ and 91 . Analyses of stand structure and nutritional status involved:

- $\quad$ estimation of numbers and weights of individual tillers and plants,

- $\quad$ estimation of dry matter (DM) weight of the above-ground part of plants,

- estimation of chlorophyll content in leaves,

- $\quad$ analysis of DM of the above-ground part of plants (for contents of $\mathrm{N}, \mathrm{P}, \mathrm{K}, \mathrm{Ca}$, and $\mathrm{Mg}$ ).

The segregation of tillers to productive and non-productive ones was performed as follows: When performing analyses, tillers were ordered according to their decreasing weight. The number of fully ripe ears per plot was taken as the number of productive tillers. In 2005, the total number of weighed tillers sampled at the growth stage $\mathrm{BBCH} 31$ was lower than the number of fully ripe ears (only tillers heavier than $1 \mathrm{~g}$ were weighed so that their number was lower than that of ears). Due to this fact, the analysis was not performed. Tillers with the highest weight at the given developmental stage were rated as productive ones and the sum of their weights represented the so-called productive biomass. This value was separated from the total weight of fresh above-ground biomass per unit area of the stand.

\subsection{Estimation of spectral characteristics of the stand}

The imaging set consisted of a multispectral camera DuncanTech MS-3100 (manufacturer Geospatial Systems, Inc., USA) with the objective Sigma 14 mm F2.8 Aspherical HSM, a notebook Acer Aspire 1362 (AMD Sempron 2800+, 512MB RAM, 60GB HD), and a framegrabber (videograbber) National Instruments NI-1428, which was connected with the notebook via PCMCIA and communicated with the camera via a CameraLink interface. Power for the whole set was supplied from a portable $42 \mathrm{Ah}$ accumulator with a $12 \mathrm{~V} / 220 \mathrm{~V}$ changer (transformer). The camera was controlled via a COM interface and the recording of images was performed in DTcontrol software. Because of a problematic connectivity with the framegrabber the notebook was later on replaced by a desktop PC (Intel Pentium II 400 Mhz, 640 MB RAM, 40 GB HDD) with a framegrabber placed in the PCI slot and with a 17" LCD monitor.

The imaging part of the camera consisted of three CCD elements with filters of the size $7.6 \times 6.2 \mathrm{~mm}$, which recorded in three bands of electromagnetic radiation - green (500-600 $\mathrm{nm}$, peak $550 \mathrm{~nm})$, red $(600-700 \mathrm{~nm}$, peak $650 \mathrm{~nm})$ and near infrared $(750-900 \mathrm{~nm}$, peak 830 $\mathrm{nm})$. 
By composing 8 bit images from CCD the so-called CIR (colour infrared) the image was obtained in false colours with the size of 1,392 x 1,039 pixels, and this was subsequently stored in a wireless TIFF format. The use of a wide $(14 \mathrm{~mm})$ objective enabled to reach (in combination with the physical size of the CCD element) a wide angle of recording (ca $26^{\circ} \mathrm{x}$ $\left.20^{\circ}\right)$.

For imaging from the height of $5.5 \mathrm{~m}$, a mobile aluminium scaffold was used (Figure 4); this corresponded with the image area $2.54 \times 1.9 \mathrm{~m}\left(4.83 \mathrm{~m}^{2}\right)$ and the spatial resolution of less than $2 \mathrm{~mm}$ per pixel. Since 2005, a set of optic etalons SphereOptics Zenith ${ }^{\circledR}$ was a part of each imaged scene to normalize the reflectance of radiation in accordance with existing light conditions. This set consisted of four polytetrafluorethylene (PTFE) etalons with exactly calibrated reflectances of $10 \%, 25 \%, 50 \%$, and $70 \%$. Used material had the so-called Lambert perfectly diffusing surface for which the intensity of reflected radiation was independent of direction of radiation incidence. From the viewpoint of field measurements resistance and washability of polytetrafluorethylene were also advantageous.

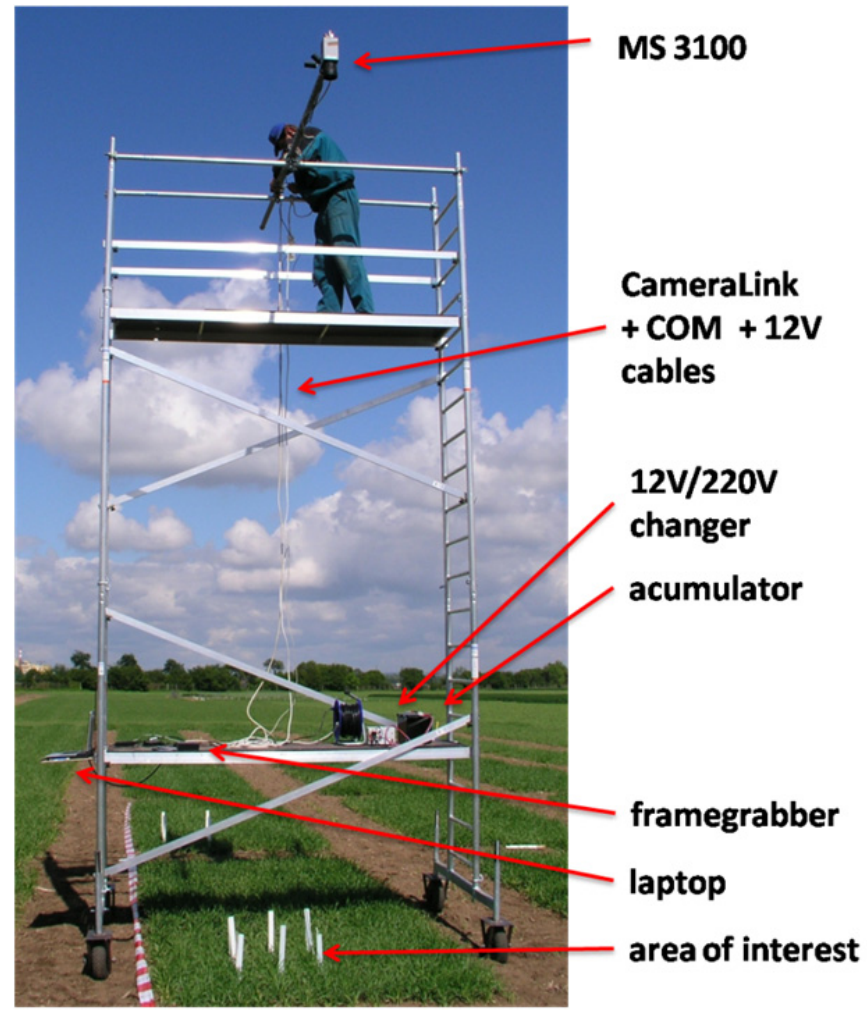

Figure 4. A view of imaging equipment

When processing recorded images, a radiometric correction was performed at first to eliminate differences in light conditions of imaging (sunny - overcast), i.e. to normalize 
reflectance. The normalization of images to constant light conditions was performed on the basis of a conversion of digital numbers (DN) of image pixels according to the measured and calibrated reflectance of a $25 \%$ optic etalon. Using images processed in this way it was thereafter possible to calculate the Normalized Difference Vegetation Index (NDVI) according to the equation NDVI $=(\mathrm{NIR}-\mathrm{R}) /(\mathrm{NIR}+\mathrm{R})$. Simultaneously, average values of $\mathrm{DN}$ and NDVI of the demarcated part of the canopy were determined on the basis of CIR and NDVI images $(\mathrm{NIR}=$ Near Infrared, $\mathrm{R}=\mathrm{Red}, \mathrm{CIR}=$ Colour Infrared $)$.

\subsection{Methods of data processing}

NDVI values were calculated from multispectral images by means of Erdas Imagine software. The obtained results were processed with Statgrafic and Statistica software using elementary statistical characteristics, analysis of variance (ANOVA) and correlation analysis.

\section{Results and discussion}

\subsection{Vegetation period}

The correlation values (Table 3 and 4) confirmed the possibility to compensate for higher stand density by available sources, which is in accordance with the law of final constant yield [43]. Its validity was later confirmed for tillering cereals by several authors [26,44,45,]. Source availability during vegetative growth and development makes plant density less important. What becomes more important is the number of tillers per plant and their performance. The increasing autonomy of tillers changes the character of cereal stand. Population of plants is gradually changing to metapopulation of tillers and in compensation relationships increases the importance of intra-plant competition [46,1,2]. Thus the relatively high correlations between stand height and production parameters, observed during tillering, can be explained, which is in accordance with our previous results [47].

Two types of relationships can be observed among shoots in the stand: relationships among plants which are more or less random, and intra-plant relationships which are controlled by the hierarchic structure of plants $[18,26]$. Reactions of plants in a stand to certain conditions are performed in the changes of intra-plant relationships which are then reflected in tiller variability. The structural conception [9], therefore, should not be only used for dividing yield to its components, which is difficult to interpret, but also for the assessment of intraplant relationships which reflect plant adaptation to specific conditions [26, 48]. It is evident from the results that plant weight is increasing with increased $\mathrm{N}$ supply. In contrast, increased plant density reduces increase in their weight and variability.

It was possible to compensate low plant density by $\mathrm{N}$ fertilization. The effect of $\mathrm{N}$ fertilization on production parameters appears in spring barley as early as at the tillering stage due to earlier $\mathrm{N}$ application (prior to seeding or at the third leaf stage). At BBCH 31, the effect of $\mathrm{N}$ fertilization was obvious in both crops.

The results confirmed that the production potential is established by the amount of the above-ground biomass per area unit and its structural composition is being formed during 
the vegetative period. Regarding the possibilities to innovate the canopy management using its spectral characteristics and remote sensing, it is important to answer the question whether the information on the amount of the above-ground biomass per area unit or on the number of plants and tillers is more important at the tillering stage. The answer is a controversial requirement to create the largest possible amount of biomass of productive tillers using the smallest possible density of plants [49]. Thus the conditions for optimum plant growth and development within the stand are defined (inter- and intra-plant competition should arise as late as possible) as well as for sufficient tillering and formation of strong adventitious root system, which provide plants with nutrients and water at subsequent growth stages. This is also confirmed by practical experience showing that less dense stands can be managed better than over-dense ones. From this stand point, even distribution of plants (optimum size and shape of nutritive area) providing the least local variability at crop canopy and thus even distribution of competition relations is important for an effective canopy management [50].

\begin{tabular}{|c|c|c|c|c|c|c|c|c|c|c|}
\hline & Parameter & $\mathrm{BBCH}$ & $n-2$ & 2 & 3 & 4 & 5 & 6 & 7 & 8 \\
\hline 1 & \multirow{2}{*}{$\begin{array}{l}\text { Number of } \\
\text { plants per } \mathrm{m}^{2}\end{array}$} & 25 & 8 & -0.222 & 0.049 & 0.521 & -0.305 & 0.225 & 0.194 & 0.014 \\
\hline & & 31 & 8 & -0.170 & -0.353 & 0.606 & 0.236 & $0.714^{*}$ & 0.599 & 0.517 \\
\hline \multirow[t]{2}{*}{2} & \multirow{2}{*}{$\begin{array}{l}\text { Average plant } \\
\text { weight }(\mathrm{g})\end{array}$} & 25 & 8 & 1 & $0.727^{*}$ & 0.480 & 0.451 & $0.887^{* *}$ & $0.898^{* *}$ & 0.795 \\
\hline & & 31 & 8 & 1 & 0.382 & 0.143 & $0.640^{*}$ & 0.554 & 0.612 & 0.560 \\
\hline \multirow[t]{2}{*}{3} & \multirow{2}{*}{$\begin{array}{l}\text { Average number } \\
\text { of tillers per } \\
\text { plant }\end{array}$} & 25 & 8 & & 1 & $0.866^{* *}$ & -0.245 & $0.703^{*}$ & $0.714^{*}$ & -0.911 \\
\hline & & 31 & 8 & & 1 & -0.330 & -0.438 & 0.028 & -0.132 & 0.212 \\
\hline \multirow[t]{2}{*}{4} & \multirow{2}{*}{$\begin{array}{l}\text { Number of tillers } \\
\text { per } \mathrm{m}^{2}\end{array}$} & 25 & 8 & & & 1 & -0.383 & $0.692^{*}$ & $0.685^{*}$ & -0.596 \\
\hline & & 31 & 8 & & & 1 & -0.192 & $0.665^{*}$ & 0.446 & 0.621 \\
\hline \multirow[t]{2}{*}{5} & \multirow{2}{*}{$\begin{array}{l}\text { Average tiller } \\
\text { weight }(\mathrm{g})\end{array}$} & 25 & 8 & & & & 1 & 0.354 & 0.390 & 0.913 \\
\hline & & 31 & 8 & & & & 1 & 0.587 & $0.728^{*}$ & 0.798 \\
\hline \multirow[t]{2}{*}{6} & \multirow{2}{*}{$\begin{array}{l}\text { Weight of } \\
\text { above-ground } \\
\text { biomass }\left(\mathrm{g} \cdot \mathrm{m}^{-2}\right)\end{array}$} & 25 & 8 & & & & & 1 & $0.988^{* *}$ & 0.449 \\
\hline & & 31 & 8 & & & & & 1 & $0.941^{* *}$ & 0.928 \\
\hline \multirow[t]{2}{*}{7} & \multirow{2}{*}{$\begin{array}{l}\text { Weight of } \\
\text { above-ground } \\
\text { dry matter } \\
\left(\mathrm{g} . \mathrm{m}^{-2}\right)\end{array}$} & 25 & 8 & & & & & & 1 & 0.737 \\
\hline & & 31 & 8 & & & & & & 1 & 0.892 \\
\hline 8 & $\begin{array}{l}\text { Stand height } \\
(\mathrm{cm})\end{array}$ & $25 / 31$ & 2 & & & & & & & $1 / 1$ \\
\hline
\end{tabular}

Table 3. Correlation between the assessed parameters in winter wheat at $\mathrm{BBCH} 25$ and 31 (*statistical significance, ${ }^{* *}$ high statistical significance) 


\begin{tabular}{|c|c|c|c|c|c|c|c|c|c|c|}
\hline & Parameter & $\mathrm{BBCH}$ & $n-2$ & 2 & 3 & 4 & 5 & 6 & 7 & 8 \\
\hline \multirow[t]{2}{*}{1} & \multirow{2}{*}{$\begin{array}{l}\text { Number of } \\
\text { plants per } \mathrm{m}^{2}\end{array}$} & 22 & 20 & -0.212 & -0.135 & $0.486^{*}$ & -0.040 & 0.304 & 0.358 & 0.048 \\
\hline & & 31 & 14 & -0.257 & -0.312 & $0.658^{* *}$ & -0.061 & $0.562^{*}$ & 0.468 & -0.014 \\
\hline \multirow[t]{2}{*}{2} & \multirow{2}{*}{$\begin{array}{l}\text { Average plant } \\
\text { weight }(\mathrm{g})\end{array}$} & 22 & 20 & 1 & $0.600^{* *}$ & 0.394 & 0.028 & $0.845^{* *}$ & $0.786^{* *}$ & $0.866^{* *}$ \\
\hline & & 31 & 14 & 1 & $0.839^{* *}$ & 0.410 & $0.610^{* *}$ & $0.775^{* *}$ & $0.812^{* *}$ & $0.802^{*}$ \\
\hline \multirow[t]{2}{*}{3} & \multirow{2}{*}{$\begin{array}{l}\text { Average } \\
\text { number of } \\
\text { tillers per plant }\end{array}$} & 22 & 20 & & 1 & $0.781^{* *}$ & $-0.485^{*}$ & $0.465^{*}$ & $0.421^{*}$ & 0.318 \\
\hline & & 31 & 14 & & 1 & 0.468 & 0.097 & $0.631^{* *}$ & $0.586^{*}$ & 0.357 \\
\hline \multirow[t]{2}{*}{4} & \multirow{2}{*}{$\begin{array}{l}\text { Number of } \\
\text { tillers per } \mathrm{m}^{2}\end{array}$} & 22 & 20 & & & 1 & $-0.466^{*}$ & $0.616^{* *}$ & $0.619^{* *}$ & 0.239 \\
\hline & & 31 & 14 & & & 1 & 0.068 & $0.888^{* *}$ & $0.779 * *$ & 0.373 \\
\hline \multirow[t]{2}{*}{5} & \multirow{2}{*}{$\begin{array}{l}\text { Average tiller } \\
\text { weight }(\mathrm{g})\end{array}$} & 22 & 20 & & & & 1 & 0.005 & 0.058 & -0.188 \\
\hline & & 31 & 14 & & & & 1 & $0.510^{*}$ & $0.625^{* *}$ & $0.847^{* *}$ \\
\hline \multirow[t]{2}{*}{6} & \multirow{2}{*}{$\begin{array}{l}\text { Weight of } \\
\text { above-ground } \\
\text { biomass } \\
\left(\mathrm{g} \cdot \mathrm{m}^{-2}\right)\end{array}$} & 22 & 20 & & & & & 1 & $0.974^{* *}$ & $0.845^{* *}$ \\
\hline & & 31 & 13 & & & & & 1 & $0.959^{* *}$ & $0.885^{* *}$ \\
\hline \multirow[t]{2}{*}{7} & \multirow{2}{*}{$\begin{array}{l}\text { Weight of } \\
\text { above-ground } \\
\text { dry matter } \\
\left(\mathrm{g} \cdot \mathrm{m}^{-2}\right)\end{array}$} & 22 & 20 & & & & & & 1 & $0.811^{* *}$ \\
\hline & & 31 & 13 & & & & & & 1 & $0.907^{* *}$ \\
\hline 8 & $\begin{array}{l}\text { Stand height } \\
(\mathrm{cm})\end{array}$ & $22 / 31$ & 12 & & & & & & & $1 / 1$ \\
\hline
\end{tabular}

Table 4. Correlation between the assessed parameters in spring barley at BBCH 22 and 31 (*statistical significance, ${ }^{* *}$ high statistical significance)

Current practice requires rapid and effective methods for stand assessment. The conventional canopy management is very laborious. Regarding a large number of tillers per assessed area (usually $0.25 \mathrm{~m}^{2}$ ) and needed number of replications, it is practically impossible to carry out their accurate identification in plants as described by Rawson [24] or Klepper et al. [51]. Based on the obtained results, the following parameters should be considered by canopy management during the vegetative period:

- density of plants after emergence,

- tillering intensity, variability of plant size and stand height during tillering,

- tiller size or number of strong tillers, their uniformity at the beginning of stem elongation,

- the amount of total above-ground biomass per unit area of a stand.

\subsection{Generative period}

The process of tiller differentiation was evaluated by means of histograms illustrating the frequency distribution of their weights. To respect given size limits of this chapter, only data about the differentiation of tillers evaluated in experimental variants in Kroměříž in 2007 are 
presented: Graph 4 contains data about winter wheat and Graph 5 informs about spring barley. As shown in these histograms, the process of tiller differentiation was influenced both by the stand density and by an $\mathrm{N}$ dose. A higher density of plants and a lack of nitrogen accelerated the process of differentiation and made it also more intensive. The separation of tillers into subgroups of productive and non-productive ones could be identified on the basis of a local minimum. In variants without application of nitrogen (variant $A$ in the experiment with winter wheat and variants $C$ and $E$ in the experiment with spring barley), symptoms of tillers separation were manifested in both crops as early as at the beginning of the stage of stem elongation ( $\mathrm{BBCH} 31)$. On the other hand, however, the fertilised variants showed in this period a marked shift of values to the left, i.e. the proportion of lighter tillers was increased due to a more intensive tillering, which was supported by nitrogen. The differentiation of tillers appeared in histograms under conditions of a lack of resources (i.e. nitrogen). The lack of resources occurred in stands with a high density of plants (Graph 5, variant E in the experiment with spring barley). Application of nitrogen prolonged processes of differentiation till the stage of heading. From the viewpoint of yield formation, a gradual differentiation of tillers is beneficial because potentially productive tillers can be preserved for a longer time interval. On the other hand, however, too dense stands can suffer from a lack of resources (e.g. during dry periods).

To estimate the production potential and predict the yield, it is an advantage to know the numbers of productive tillers and their critical weight for the transition from the vegetative to the generative stage of growth and development. In our analyses this was done in two different ways:

- $\quad$ basing on the position of local minima in histograms (Graphs 4 and 5),

- by deduction of the strongest tillers (evaluated on the basis of the number of ears at $\mathrm{BBCH}$ 91) from their total number.

The observed critical weights of winter wheat and spring barley individual tillers were approximately $2 \mathrm{~g}$ and $1.5 \mathrm{~g}$, respectively.

The separation of tillers into two groups, i.e. vegetative and generative (potentially productive) ones enabled us to determine the share of productive and non-productive biomass in the total above-ground biomass of the stand. This value can be an important indicator of the effectiveness of farming inputs into the crop cultivation. Thereafter an analysis of metapopulations of potentially productive tillers was performed.

Further analyses were focused on the evaluation of relationships between populations of productive and non-productive tillers. Correlations between total above-ground biomass and biomass of potentially productive tillers were positive and statistically highly significant while correlations between the total above-ground biomass and the share of the biomass of potentially productive tillers were very variable. Similar values and a similar character of correlations were also between the content of nitrogen in the total above-ground biomass and biomass of potentially productive tillers and also their share in the total aboveground biomass on the other hand (Table 5). Analysis of variability (Table 6) revealed low 

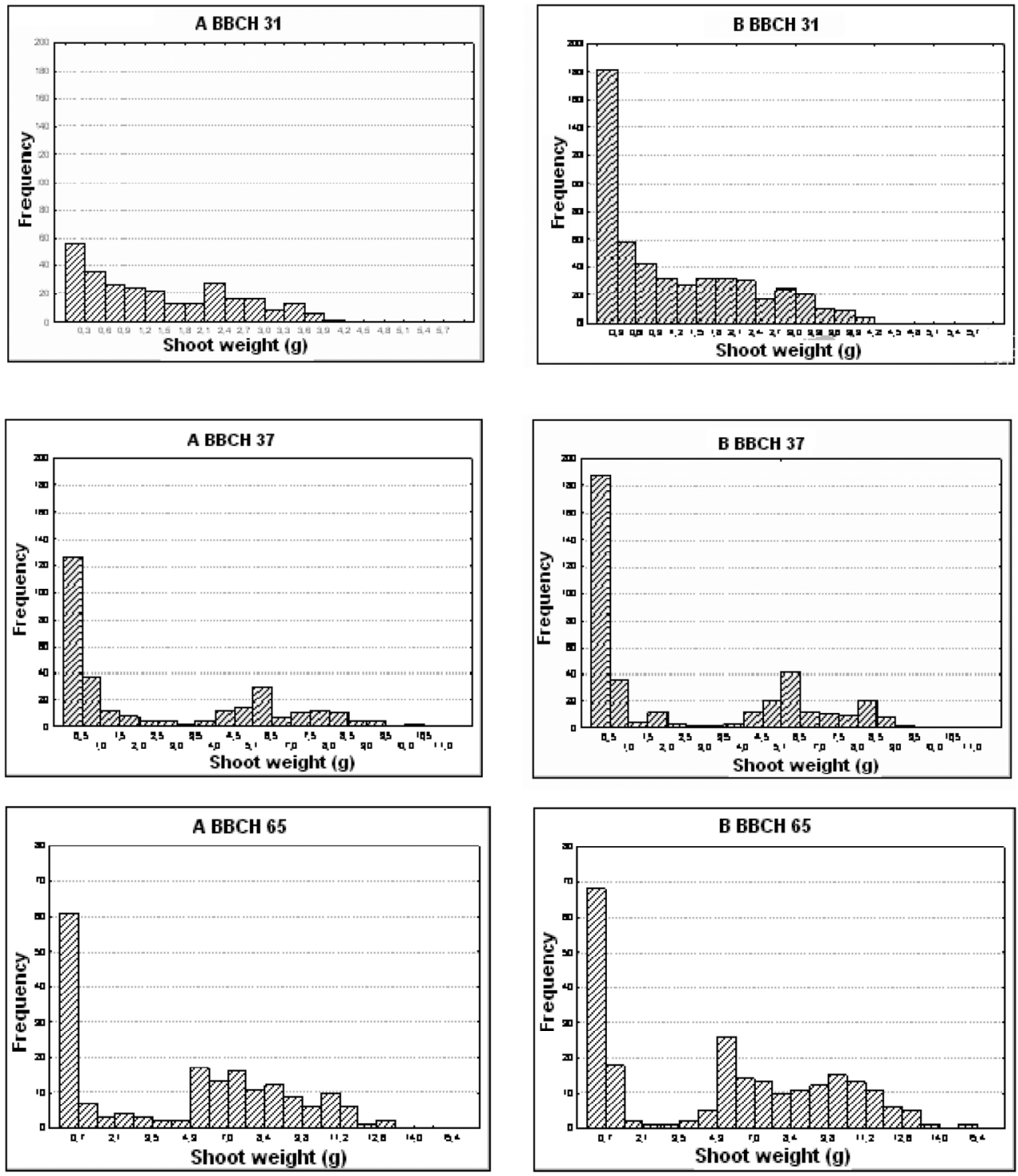

Graph 4. Development of tillers differentiation in winter wheat variety 'Cubus' in contrast variants of stand structure at the location of Kroměříž in 2007 (left side Variant A, right side Variant B) 

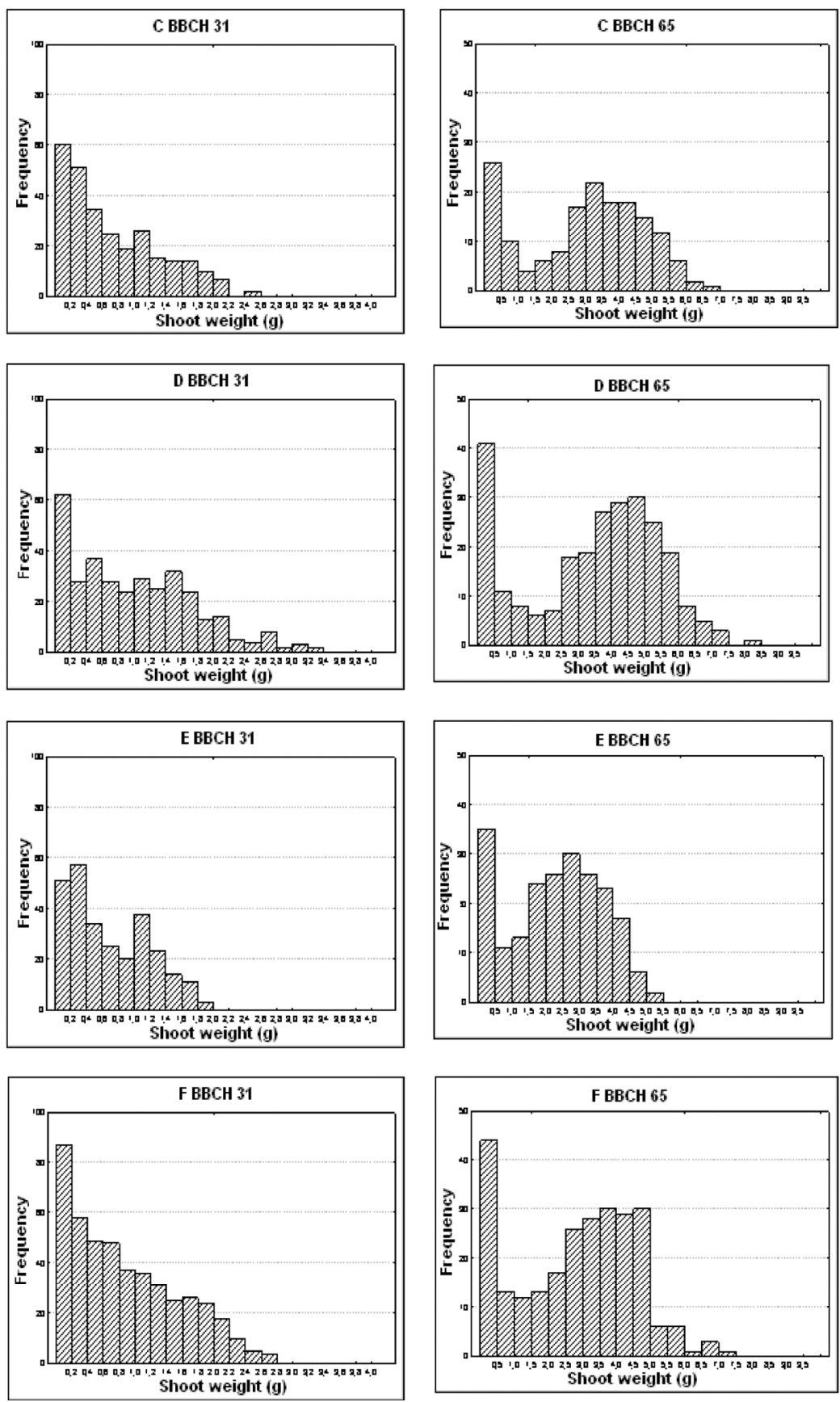

Graph 5. Development of tillers differentiation in spring barley variety 'Malz' in contrast variants of stand structure at the location of Kroměříž in 2007 (from top to bottom Variants C, D, E, F) 
values (i.e. less than a half) of the $\mathrm{CV}$ for the proportion of biomass of productive tillers in the total above-ground biomass (ranging from 7.06 to $15.79 \%$ and from 7.37 to $17.46 \%$ for winter wheat and spring barley, respectively) while values of CV for other traits under study ranged from 29.81 to $54.43 \%$. Analogical correlations calculated on the basis of all and of productive tillers showed a similar character but they were lower (Table 7). Values of CV for correlated traits (Table 8 ) were mostly higher, including the proportion of productive tillers in their total number (22.85 to $26.11 \%$ and 12.67 to $32.12 \%$ for winter wheat and spring barley, respectively). Basing on this observation, it can be concluded that there is a close relationship between the total above-ground biomass and that of potentially productive tillers already at the stage of stem elongation. Because of a low variability the proportion of potentially productive tillers in the total above-ground biomass can be used for the estimation of a productive potential of the crop. This finding can be useful for more effective methods of canopy control based on spectral characteristics and on indirect estimation of above-ground biomass using the NDVI (Normalized Difference Vegetation Index).

\begin{tabular}{ccccccc}
\hline \multirow{3}{*}{ Crop } & $\begin{array}{c}\text { Develop } \\
\text {-mental } \\
\text { stage } \\
\text { BBCH }\end{array}$ & n-2 & $\begin{array}{c}\text { Total and } \\
\text { productive } \\
\text { biomass }\end{array}$ & $\begin{array}{c}\text { Total biomass } \\
\text { and share of } \\
\text { productive } \\
\text { biomass }\end{array}$ & $\begin{array}{c}\text { N-content in } \\
\text { bio-mass and } \\
\text { productive } \\
\text { biomass }\end{array}$ & $\begin{array}{c}\text { N-content in } \\
\text { biomass and share } \\
\text { of productive } \\
\text { biomass }\end{array}$ \\
\hline Winter & 31 & 8 & $0.9111^{* *}$ & 0.0850 & $0.8657^{* *}$ & 0.1841 \\
\cline { 2 - 7 } wheat & 37 & 6 & $0.9659^{* *}$ & -0.3515 & $0.9409^{* *}$ & -0.1133 \\
\cline { 2 - 7 } & 65 & 8 & $0.9720^{* *}$ & 0.2182 & $0.9130^{* *}$ & -0.2676 \\
\hline Spring & 31 & 14 & $0.9501^{* *}$ & $-0.7810^{* *}$ & $0.8847^{* *}$ & $-0.7603^{* *}$ \\
barley & 37 & 6 & $0.9995^{* *}$ & $0.9657^{* *}$ & $0.9664^{* *}$ & $0.8949^{* *}$ \\
\cline { 2 - 7 } & $55 / 65$ & 18 & $0.9835^{* *}$ & 0.1695 & $0.8743^{* *}$ & 0.3365 \\
\hline
\end{tabular}

Table 5. Relationships in stands of winter wheat and spring barley (*statistical significance, ${ }^{* *}$ high statistical significance)

\begin{tabular}{|c|c|c|c|c|c|c|c|c|c|c|}
\hline \multirow{3}{*}{ Crop } & \multirow{3}{*}{$\begin{array}{c}\text { Develop- } \\
\text { mental } \\
\text { stage } \\
\mathrm{BBCH}\end{array}$} & \multirow{3}{*}{$n-2$} & \multicolumn{8}{|c|}{ Trait } \\
\hline & & & \multicolumn{2}{|c|}{ Total biomass } & \multicolumn{2}{|c|}{$\begin{array}{l}\mathrm{N} \text {-content in } \\
\text { biomass }\end{array}$} & \multicolumn{2}{|c|}{$\begin{array}{l}\text { Productive } \\
\text { biomass }\end{array}$} & \multicolumn{2}{|c|}{$\begin{array}{c}\text { Share of } \\
\text { productive } \\
\text { tillers }\end{array}$} \\
\hline & & & $\begin{array}{l}\text { Mean } \\
\left(\mathrm{g} \cdot \mathrm{m}^{-2}\right)\end{array}$ & $\begin{array}{l}\mathrm{CV} \\
(\%)\end{array}$ & $\begin{array}{l}\text { Mean } \\
\left(\mathrm{g} \cdot \mathrm{m}^{-2}\right)\end{array}$ & $\begin{array}{l}\mathrm{CV} \\
(\%)\end{array}$ & $\begin{array}{l}\text { Mean } \\
\left(\mathrm{g} \cdot \mathrm{m}^{-2}\right)\end{array}$ & $\begin{array}{l}\mathrm{CV} \\
(\%)\end{array}$ & $\begin{array}{l}\text { Mean } \\
\left(\mathrm{g} \cdot \mathrm{m}^{-2}\right)\end{array}$ & $\begin{array}{l}\text { CV } \\
(\%)\end{array}$ \\
\hline \multirow{3}{*}{$\begin{array}{l}\text { Winter } \\
\text { wheat }\end{array}$} & 31 & 10 & 1,586 & 33.12 & 8.78 & 39.86 & 1031 & 38.74 & 0.65 & 15.79 \\
\hline & 37 & 8 & 3032 & 30.76 & 12.65 & 46.64 & 2667 & 29.81 & 0.89 & 7.06 \\
\hline & 65 & 10 & 3775 & 35.00 & 16.14 & 45.13 & 3533 & 34.31 & 0.94 & 7.57 \\
\hline \multirow{3}{*}{$\begin{array}{l}\text { Spring } \\
\text { barley }\end{array}$} & 31 & 16 & 1376 & 39.58 & 6.55 & 36.24 & 1060 & 30.99 & 0.80 & 12.80 \\
\hline & 37 & 8 & 2430 & 54.43 & 8.03 & 49.95 & 2573 & 50.36 & 0.84 & 17.46 \\
\hline & $55 / 65$ & 20 & 2777 & 38.19 & 9.83 & 34.46 & 2485 & 40.44 & 0.89 & 7.37 \\
\hline
\end{tabular}

Table 6. Mean values and coefficients of variation for traits in stands of winter wheat and spring barley 


\begin{tabular}{ccccccc}
\hline \multirow{2}{*}{ Crop } & Develop- & n-2 & \multicolumn{5}{c}{ Correlation coefficient between } \\
\cline { 3 - 7 } & $\begin{array}{c}\text { mental } \\
\text { stage } \\
\text { BBCH }\end{array}$ & $\begin{array}{c}\text { Total number } \\
\text { of tillers and } \\
\text { number of } \\
\text { productive } \\
\text { tillers }\end{array}$ & $\begin{array}{c}\text { Total number } \\
\text { of tillers and } \\
\text { share of } \\
\text { productive } \\
\text { tillers }\end{array}$ & $\begin{array}{c}\text { N-content in } \\
\text { biomass and } \\
\text { number of } \\
\text { productive } \\
\text { tillers }\end{array}$ & $\begin{array}{c}\text { N-content } \\
\text { in biomass } \\
\text { and share of } \\
\text { productive } \\
\text { tillers }\end{array}$ \\
\hline Winter & 31 & 8 & 0.5262 & -0.5621 & $0.7987^{* *}$ & 0.0123 \\
\cline { 2 - 7 } wheat & 37 & 6 & $0.8140^{* *}$ & $-0.7203^{* *}$ & $0.7729^{*}$ & -0.6106 \\
\cline { 2 - 7 } & 65 & 8 & $0.8260^{* *}$ & $-0.6578^{*}$ & $0.8114^{* *}$ & $0.5930^{*}$ \\
\hline Spring & 31 & 14 & $0.7107^{* *}$ & $-0.7505^{* *}$ & $0.5803^{*}$ & $-0.7458^{* *}$ \\
\cline { 2 - 7 } barley & 37 & 6 & 0.3323 & 0.0008 & $0.9156^{* *}$ & $0.8332^{*}$ \\
\cline { 2 - 7 } & $55 / 65$ & 18 & $0.9007^{* *}$ & -0.0612 & $0.7669^{* *}$ & 0.1316 \\
\hline
\end{tabular}

Table 7. Relationships in stands of winter wheat and spring barley ( ${ }^{*}$ statistical significance, ${ }^{* *}$ high statistical significance)

\begin{tabular}{|c|c|c|c|c|c|c|c|c|c|c|}
\hline \multirow{3}{*}{ Crop } & \multirow{3}{*}{$\begin{array}{c}\text { Develop- } \\
\text { mental } \\
\text { stage } \\
\text { BBCH }\end{array}$} & \multirow{3}{*}{ n-2 } & \multicolumn{8}{|c|}{ Trait } \\
\hline & & & \multicolumn{2}{|c|}{$\begin{array}{l}\text { Total number of } \\
\text { tillers }\end{array}$} & \multicolumn{2}{|c|}{$\begin{array}{l}\mathrm{N} \text {-content in } \\
\text { biomass }\end{array}$} & \multicolumn{2}{|c|}{$\begin{array}{c}\text { Number of } \\
\text { productive tillers }\end{array}$} & \multicolumn{2}{|c|}{$\begin{array}{c}\text { Share of } \\
\text { productive } \\
\text { tillers }\end{array}$} \\
\hline & & & $\begin{array}{l}\text { Mean } \\
\left(\mathrm{g} \cdot \mathrm{m}^{-2}\right)\end{array}$ & $\begin{array}{l}\text { CV } \\
(\%)\end{array}$ & $\begin{array}{l}\text { Mean } \\
\left(\mathrm{g} \cdot \mathrm{m}^{-2}\right)\end{array}$ & $\begin{array}{l}\mathrm{CV} \\
(\%)\end{array}$ & $\begin{array}{l}\text { Mean } \\
\left(\mathrm{g} . \mathrm{m}^{-2}\right)\end{array}$ & $\begin{array}{l}\mathrm{CV} \\
(\%)\end{array}$ & $\begin{array}{l}\text { Mean } \\
\left(\mathrm{g} \cdot \mathrm{m}^{-2}\right)\end{array}$ & $\begin{array}{l}\text { CV } \\
(\%)\end{array}$ \\
\hline \multirow{3}{*}{$\begin{array}{l}\text { Winter } \\
\text { wheat }\end{array}$} & 31 & 10 & 1583 & 26.98 & 8.78 & 39.86 & 483 & 22.10 & 0.3163 & 26.11 \\
\hline & 37 & 8 & 1072 & 36.83 & 12.65 & 46.64 & 520 & 27.49 & 0.5120 & 22.85 \\
\hline & 65 & 10 & 718 & 34.21 & 16.14 & 45.13 & 510 & 24.80 & 0.7495 & 25.79 \\
\hline \multirow{3}{*}{$\begin{array}{l}\text { Spring } \\
\text { barley }\end{array}$} & 31 & 16 & 1324 & 33.68 & 6.55 & 36.24 & 676 & 21.09 & 0.5400 & 24.76 \\
\hline & 37 & 8 & 1172 & 11.62 & 8.03 & 49.95 & 609 & 35.06 & 0.5200 & 32.12 \\
\hline & $55 / 65$ & 20 & 932 & 25.15 & 9.83 & 34.46 & 625 & 26.52 & 0.6700 & 12.67 \\
\hline
\end{tabular}

Table 8. Average values and coefficients of variation for traits in stands of winter wheat and spring barley

The stand structure is a result of a simultaneous growth of individual plants within the framework of a population and changes in dependence on dynamics of growth processes, which are limited both spatially and temporally, in the course of the growing season. The temporal limitation results from developmental changes taking place during the life cycle of plants and while the spatial limitation is given by the size of their nutritive area and by available resources. These limitations are mutually interlinked and can stand for each other; this results from the law of "final constant yield" [43]. In practice this means that a shortening of the growing season, and especially of the period of generative growth and development, which is characterized by intensive growth, can be compensated by higher sowing rates and vice versa. An adequate supply of water and nutrients reduces the decrease in numbers of tillers both in dense and thin stands. Under conditions of abundance of resources the highest yields can be obtained in stands with a high productive density, which 
can be obtained on the basis of a lower number of plants. This can be explained by the fact that the competition is postponed till the end of the period of stem elongation. This observation corresponds with results of our earlier experiments, in which it was found out that the highest grain yield could be reached on the basis of maximum amount of aboveground biomass and density of productive stems at the minimum density of plants [49].

Corroborated were also conclusions drawn by Muravjev [8] that under favorable conditions the uniformity of stems and ears can be increased by competition induced in the period of stem elongation. Such a competition results in the selection of the strongest and the most vigorous tillers. However, the developmental biology of cereals permits only a relative synchronization of growth and development. Allometry and temporal sequence of the establishment and formation of identical organs (modules) support and work in favor of their increasing variability [3]).

An uneven growth of plants and tillers as well as their competition are the major factors which influence the stand structure. It is very difficult to evaluate directly the intensity of mutual interactions and competition of plants growing together only on the basis of the depletion of available resources [52]. For that reason the ecologists use the size distribution of plants as a suitable indicator of these relationships and of changes taking place in the structure of plant populations. The use of this indicator enabled to characterize the differentiation of tillers and to define relationships between potentially productive tillers on the one hand and non-productive ones on the other.

An effective utilization of growing factors and farming inputs is dependent on the fulfillment of two controversial requirements:

- formation of a maximum possible amount of above-ground biomass,

- establishment of a maximum possible proportion of productive tillers (stems) in the total above-ground biomass.

Basing on our results, it can be concluded that there is a close relationship between the total above-ground biomass and $\mathrm{N}$-content in the total above-ground biomass on the one hand and the biomass of potentially productive tillers already in the period of stem elongation on the other. Because of a low degree of variability it is possible to use the share of potentially productive tillers in the total above-ground biomass for the estimation of overall productive capacity of a stand. This creates preconditions for a more efficient use of indirect methods of canopy assessment on the basis of its spectral characteristics, e.g. when using of the NDVI for optimization of the canopy management in dependence on the intensity of inputs. The obtained results also indicated that the relationships calculated at the level of biomass were more exact than those obtained by counting of the number of tillers. This indicates that values of the NDVI (and possibly also of other spectral canopy characteristics) will enable to obtain more exact estimation of the amount of above-ground biomass (both total and productive) than of its structure (numbers of plants and tillers).

The results also indicate that there is a possibility of the occurrence of various, dynamically changing situations in cereal crops. The population concept applied in studies concerning 
modular units (tillers) enabled to create a unifying base for these relatively chaotic phenomena. They can therefore be used when studying and testing new methods of efficient and areal screening of the condition of cereal stands by means of spectral characteristic and technologies of remote and terrestrial sensing [23,53,54].

\subsection{Reproductive period}

Although the differentiation and abortion of vegetative tillers is still proceeding, the process of yield structure formation is practically terminated. Shoot system has no more the adaptation function, which is now provided by ear structures and reproductive organs. Adaptation proceeds by grain filling; the importance of physiological processes taking part in it is increasing. These are usually explained by the theory of source $x$ sink $[37,55,56]$, which has been long applied in scientific papers oriented to yield formation in cereal crops. It is generally accepted that biomass of productive stems at anthesis correlates with the number of grains per $\mathrm{m}^{2}$, and the duration of leaf area correlates with the of 1000-grain weight [36].

Analysis of stand structure was followed by analyses of yield structure. It was logical that in winter wheat (Table 9) higher yield was obtained in variant B compared with variant A by 15.7 \% in Žabčice and by 14.8 \% in Kroměříž, due to higher number of ears and kernels per $\mathrm{m}^{2}$. Yield differences among variants were just under the limits of statistical significance (Table 11), on the other hand, the effects of year and locations on yield were highly significant. Difference was found between the variants in 1000-grain weight. In spring barley, the highest yield at both locations was reported in variant D and the lowest in variant $\mathrm{E}$ (Table 10), which was in accordance with the results of stand structure analyses. Yield differences among the variants were highly significant (Table 12). The effect of year on the yield was also statistically highly significant but the effect of location was only statistically significant. Similarly to winter wheat, the highest number of ears and grains per $\mathrm{m}^{2}$ (Table 10) was formed in the best performing variant D. However, the highest number of grains in ear (21.14) was found in Kroměřǐž, and high values of 1000-grain weight (44.79 g in Žabčice and $44.34 \mathrm{~g}$ in Kroměříz) were found at both locations unlike of winter wheat. Variant $C$ in Žabčice and $E$ in Kroměříž were the least-yielding. They were characterized by the lowest number of grains per $\mathrm{m}^{2}$ and the lowest 1000-grain weight. The results indicate an apparent effect of different pedological-climatic conditions of the locations on grain yield formation. Under drier climatic conditions in Žabčice, higher seeding rate had a positive effect on yield, while at the more productive location of Kroměřiž with more balanced ratio of temperatures and precipitation, lower seeding rate in combination with $\mathrm{N}$ fertilization was beneficial. High density of plants in variant $E$ in Kroměříž caused obviously a long-term $\mathrm{N}$ deficiency, which resulted in higher variability of weight in productive tillers at ripening.

The results also confirmed high yield determination by the number of grains per $\mathrm{m}^{2}$, which corresponds with the data from literature. Further, negative correlation between 1000-grain weight and both ear number per $\mathrm{m}^{2}$ and yield was confirmed in winter wheat. This can be explained by modular structure of cereal plants. High yields are usually obtained by higher 


\begin{tabular}{lcccc}
\hline \multirow{2}{*}{ Parameter / Variant } & \multicolumn{2}{c}{ Žabčice } & \multicolumn{2}{c}{ Kroměříž } \\
\cline { 2 - 5 } & A & B & A & B \\
\hline Number of ears per $1 \mathrm{~m}^{2}$ & 374 & 456 & 543 & 665 \\
\hline Number of grains per ear & 34.85 & 31.79 & 31.51 & 31.82 \\
\hline Number of grains per $\mathrm{m}^{2}$ & 12928 & 14516 & 16875 & 21149 \\
\hline 1000-grain weight $(\mathrm{g})$ & 38.17 & 41.26 & 42.78 & 39.76 \\
\hline Grain yield $\left(\mathrm{g} \cdot \mathrm{m}^{-2}\right)$ & 516 & 597 & 718 & 824 \\
\hline
\end{tabular}

Table 9. Winter wheat yield components in Žabčice (two-year averages; 2006 and 2007), and in Kroměříž (three-year averages; 2005-2007)

\begin{tabular}{lcccccccc}
\hline \multirow{2}{*}{ Parameter / Variant } & \multicolumn{4}{c}{ Žabčice } & \multicolumn{4}{c}{ Kroměříž } \\
\cline { 2 - 10 } & $\mathrm{C}$ & $\mathrm{D}$ & $\mathrm{E}$ & $\mathrm{F}$ & $\mathrm{C}$ & $\mathrm{D}$ & $\mathrm{E}$ & $\mathrm{F}$ \\
\hline Number of ears per $\mathrm{m}^{2}$ & 560 & 634 & 630 & 610 & 545 & 715 & 588 & 679 \\
\hline Number of grains per ear & 19.88 & 19.47 & 19.78 & 20.33 & 18.55 & 21.14 & 17.17 & 19.84 \\
\hline Number of grains per $\mathrm{m}^{2}$ & 11284 & 12650 & 12656 & 12316 & 10117 & 15044 & 10179 & 13439 \\
\hline 1000-grain weight $(\mathrm{g})$ & 43.92 & 44.79 & 44.00 & 42.70 & 44.55 & 44.34 & 41.41 & 43.01 \\
\hline Grain yield $\left(\mathrm{g}^{-2} \mathrm{~m}^{-2}\right.$ & 507 & 583 & 575 & 540 & 451 & 668 & 420 & 576 \\
\hline
\end{tabular}

Table 10. Spring barley yield components in Žabčice (two-year averages; 2005 and 2007), and in Kroměříž (three-year averages; 2005-2007)

\begin{tabular}{lrrrrr}
\hline Source & \multicolumn{1}{c}{ Sum of squares } & Df & Mean square & F-ratio & \multicolumn{2}{c}{ P-value } \\
\hline Location & 25.557 & 1 & 25.557 & 42.37 & 0.000 \\
\hline Year & 56.968 & 2 & 28.484 & 47.22 & 0.000 \\
\hline Variant & 1.935 & 1 & 1.935 & 3.21 & 0.083 \\
\hline Replication & 1.894 & 3 & 0.631 & 1.05 & 0.386 \\
\hline Residual & 18.097 & 30 & 0.603 & & \\
\hline Total & 105.014 & 37 & & & \\
\hline
\end{tabular}

Table 11. Analysis of variance of winter wheat yield

\begin{tabular}{lrrrrr}
\hline Source & Sum of squares & Df & Mean square & F-ratio & P-value \\
\hline Location & 3.965 & 1 & 3.965 & 4.12 & 0.046 \\
\hline Year & 293.027 & 2 & 146.513 & 152.19 & 0.000 \\
\hline Variant & 17.826 & 3 & 5.942 & 6.17 & 0.001 \\
\hline Replication & 0.424 & 3 & 0.141 & 0.15 & 0.932 \\
\hline Residual & 65.466 & 68 & 0.963 & & \\
\hline Total & 378.274 & 77 & & & \\
\hline
\end{tabular}

Table 12. Analysis of variance of spring barley yield 
number of ears formed in the plants of a certain stand. Ears in later formed tillers have usually smaller kernels. Then, it is clear that high yields are characterized by high number of grains per $\mathrm{m}^{2}$ and lower 1000-grain weight. Higher 1000-grain weight in variant B in Žabčice (Table 9) can be explained by the fact that the stand was created predominantly by main stems. Number of ears at harvest was lower than the number of germinating seeds sown. In spring barley (Table 10), manifestation of these relationships was not unambiguous either. It is likely due to the fact that compensation processes were not been fully employed as it is evident from low numbers of grains per $\mathrm{m}^{2}$ and grain yields at both locations.

Recently, an interesting discussion on this subject has been reported between Sinclar and Jamieson [57] and Fischer [58]. Both parts consider accumulation of sources till anthesis as important to grain yield determination. However, they differ in their opinion to the hypothesis that in the post-anthesis period yield is predominantly determined by kernel number. Sinclar and Jamieson [57] stated that yield is fundamentally driven by carbon and nitrogen resource accumulation, essentially independent of grain number. Fischer [58] considers the number of grains formed during anthesis, under optimal conditions, as essential for yield formation. Our current and former results concerning grain formation [41] are rather in accordance with the conception of Sinclar and Jamieson [57]. Changes in metapopulations of grains during their formation can be explained based on trophic approach and the rules of plant population biology. The sources for grain formation can be considered analogically to carrying capacity of the environment used to explain processes in plant populations [42].

During the reproductive growth and development, stand structure practically cannot be further influenced. Canopy control should, therefore, be focused on the assessment of the active green area and its heath status. Consequent crop management should predominantly be oriented to maintaining the functionality of the active green area as long as possible with emphasis on the flag leaf and ear supplying assimilates to the forming grains. The following stand parameters can be considered important during the reproductive period:

- number of productive shoots,

- canopy closure,

- total aboveground biomass,

- biomass of productive shoots,

- active green area, its duration and health status,

- resistance to lodging.

\subsection{Canopy spectral characteristic - NDVI}

NDVI, as the most frequently used spectral characteristic of the vegetation cover, is used above all for the assessment of the total amount of aboveground biomass per unit area. It is also known that NDVI is well correlated with the total biomass within the period of intensive growth but during canopy senescence the correlation gradually decreases [59]. This was also confirmed in our cereal canopy investigations. Correlations between NDVI 
and different canopy characteristic are presented in tables 13,14,15 for winter wheat and 16, 17, 18 for spring barley (see Appendix part).

Higher values of NDVI indicated:

- a greater amount of biomass and its dry matter per $\mathrm{m}^{2}$, this corresponded with higher values of LAI, above all in the period of tillering (in spring barley) and in the period of stem elongation (winter wheat)

- a greater average weight of plants, a higher number of tillers per plant, and a higher number of plants per $\mathrm{m}^{2}$ in the period of tillering,

- a greater average weight of tillers and a higher number of tillers per $\mathrm{m}^{2}$ at the beginning of stem elongation,

- a more intensive green colour of the stand, which indicated a better nutritional status of the stand as far as nitrogen supply was concerned,

- a higher content of chlorophyll, above all in biomass of productive tillers.

This means that NDVI is positively correlated with the amount of aboveground biomass and its colour. Similar values of NDVI may obviously indicate either a greater amount of aboveground biomass with a nitrogen deficiency or a smaller amount of biomass in a good nutritional condition. It is also difficult to estimate on the basis of NDVI whether a given amount of aboveground biomass was produced by a higher number of less tillering plants or, on the contrary, by a lower number of plants with a higher number of tillers. This means that correlations between morphological (structural) and the physiological parameters of the stand condition and values of NDVI require further investigations. This is obviously one of the reasons of different results presented in papers dealing with possibilities of application of NDVI for the assessment of nutritional condition of crops and for the prediction of yields and quality of cereal grains.

Freeman et al. [60] found out weak correlations between NDVI and grain yield and grain protein content. These authors also mentioned that in the course of growing season there were no consistent relationships between NDVI and content of nitrogen in grain or in straw in different locations and years. Aparicio et al. [61] mentioned that, within the period from the stem elongation to ripening of grains, it was possible to explain $52 \%$ and $39 \%$ of variability in yields of durum wheat grown under and without irrigation, respectively, by means of NDVI values. Fetch et al. [62] reported a low efficiency of NDVI when applied for the determination of agronomic factors in barley (5-77\%). In spite of this, however, they concluded that the estimation of canopy reflectance might be a potential tool for the assessment of agronomic factors. At the same time they also pointed out that the effect of cultivars and developmental stage of on obtained results may be also important.

On the other hand, Zhao et al. [63] reported that vegetation indexes characterizing the canopy reflectance in green and red bands of electromagnetic spectrum were correlated highly significantly with the content of nitrogen in leaves at the stage of anthesis and with the protein content in wheat grains. They also mentioned a possibility of the use of correlations between spectral indexes and water content in leaves for the estimation of the protein content in grains. Jorgensen et al. [64] confirmed the possibility of the assessment of 
the stand nutritional condition by imaging in three 2-nm wide bands (450, 700, and $810 \mathrm{~nm}$ ) which indicate well the lack of nutrients. Zhang et al. [65] mention 82-94 \% and 55-70\% of determination using an NDVI-based regression model and validating experimental data from different locations, respectively. They concluded that NDVI can be used for remote sensing of nitrogen supply and nutritional status of stands. Similarly, Reyniers et al. [23] report close correlations between NDVI values and yield and N-content in grain at heading. Alvaro et al. [66] found out strong correlations between NDVI and growth characteristics and mentioned that the reliability of spectral reflectance measurement and non-destructive nature convert this method into a promising tool for the assessment of growth traits in spaced individual plants.

Negative correlations between NDVI and CV of plant weights and tillers identified in our investigations also indicate the importance of a spatial distribution of plants. This effect of stand heterogeneity should be taken into account when interpreting values of NDVI especially within the period before a canopy closure, i.e. usually till the beginning of the stem elongation (BBCH 31). The assessment of NDVI values in this period could be used for the evaluation of quality of stand establishment (i.e. uniformity of spatial distribution of individual plants). Nevertheless, Flowers et al. [20] mention the existence of close correlations between NIR digital counts and tiller density at BBCH $25(\mathrm{r}=0.67-0.87)$ and also Philips et al. [22] recommended to use a high determination of the correlation between NDVI and density of tillers at BBCH $25\left(r^{2}=0.67-0.99\right)$ for a variable application of nitrogen.

The contemporary level of knowledge enables a practical application of NDVI, especially for the evaluation of cereal crops heterogeneity in precision agriculture [23]. A great advantage is a possibility of quick and areal evaluation of canopy enabling variable cropping measures. In spring barley, this can be used within the period from stem elongation till the beginning of grain formation. Later on, when the canopy is already senescent, the correlation between NDVI and production traits is not so strong, which is mentioned by many authors $[59,67,68]$. This was confirmed partly by low and insignificant values of correlation coefficients between NDVI and productive traits and partly by results of variance analysis, which revealed lower values of NDVI during grain filling (BBCH 87).

Regarding the fact that NDVI correlates the most with the amount of aboveground biomass, it can be expected that it is potentially usable also for an indirect assessment of local differences in the stand microclimate from the viewpoint of the spread of fungal diseases. Relationships between NDVI and productive traits of the stand are the most significant within the period of stem elongation it can be concluded that for winter wheat the NDVI could be used for a variable application of nitrogen production doses or for growth regulators to protect stands against lodging. As usual, these measures are taken at the beginning of stem elongation. At later stages of growth and development (i.e. after anthesis) the relationships between NDVI and productive characteristics of the stand are not so significant. This is confirmed partly by low and insignificant correlations between NDVI and productive traits and partly by results of ANOVA which revealed lower values of NDVI at anthesis (BBCH 65). 


\section{Conclusions}

\subsection{Vegetative period}

The changing plant density and availability of sources results, in cereals during the vegetation period and development, in changes of tillers number and size. Both the factors influence the organization of canopy structure. The tillering intensity affects the formation of adventitious roots, thus creating conditions for water and nutrients uptake.

Due to different fertilization scheme, these processes are different in winter wheat and spring barley. In winter wheat, the assessed production parameters were first influenced by different seed rate and later by different $\mathrm{N}$ fertilization in the regenerative doses at $\mathrm{BBCH}$ 23. In spring barley, $\mathrm{N}$ was applied prior to seeding or at the third leaf stage and the first assessment was only carried out at tillering (BBCH 22). At this time, all fertilized variants manifested higher values in all production parameters.

During tillering, the influence of plant density on the total amount of the above-ground biomass and dry matter per $\mathrm{m}^{2}$ decreased and the influence of tillers number increased in both crops. Increasing plant density resulted in increase in stand height and decrease of the average weight and number of tillers per plant.

Due to higher density of stand caused by higher seed rate or higher $\mathrm{N}$ dose, the competition in the stand increased, which influenced the variability in plant and tiller size. Higher interplant competition was expressed by lower values of the CV for plant weight and number of tiller per plant. On the other hand, intra-plant competition increased the values of CV for tiller weight. These effects were most expressed at $\mathrm{BBCH} 31$ in variants with higher seed rate and $\mathrm{N}$ fertilization in both crops.

Canopy management during the vegetative growth should predominantly be focused on the following parameters:

- density of emerged plants,

- intensity of tillering, variability in plant weight (size) and stand height during tillering,

- $\quad$ strong tillers and their uniformity at the beginning of stem elongation.

\subsection{Generative period}

A higher density of plants and a lack of nitrogen accelerated the differentiation of tillers and made it more intensive. A segregation of tillers into two subgroups (i.e. productive and nonproductive ones) was possible due to an identification of the local minimum in histogram of their weight distribution. In variants without the nitrogen application, symptoms of the minimum appeared already at the beginning of the stage of stem elongation.

Variants fertilized by nitrogen showed in this period a marked shift of values to the left, i.e. the proportion of lighter tillers was increased due to a more intensive tillering. The differentiation of tillers occurred under conditions of a lack of nitrogen. Under conditions of a high density of plants this situation occurred earlier. Application of nitrogen prolonged 
processes of differentiation till the end of the heading. From the viewpoint of yield formation, a gradual differentiation of tillers is beneficial because potentially productive tillers can be preserved for a longer time interval. On the other hand, however, too dense stands can suffer under conditions of lacking resources (e.g. during dry periods).

The observed critical weights of winter wheat and spring barley individual tillers for transition from vegetative to generative growth and development were about $2 \mathrm{~g}$ and $1.5 \mathrm{~g}$, respectively.

The separation of tillers into two groups, i.e. vegetative and generative (potentially productive) ones enabled to determine the share of productive and non-productive biomass in the total above-ground biomass. This value can be an important indicator of the effectiveness of farming inputs into the crop cultivation.

The application of nitrogen was manifested in:

- a higher weight of an average tiller even under conditions of an increased stand density;

- $\quad$ lower values of CV for tiller weight.

As compared with potentially productive tillers, the values of $\mathrm{CV}$ for the weight of all tillers were mostly doubled in the majority of cases due to their two-peak distribution. Decreased variability of productive tillers was associated with their higher density and with a higher amount of productive biomass per unit area of the stand.

Correlations between total above-ground biomass and that of potentially productive tillers were positive and statistically highly significant while correlations existing between the total above-ground biomass and the share of biomass of potentially productive tillers were very variable. Similar values and a similar character of correlations were found also between the content of nitrogen in the total above-ground biomass on the one hand and biomass of potentially productive tillers and their share in the total above-ground biomass on the other. As compared with other traits under study, values of the $\mathrm{CV}$ for the proportion of productive tillers biomass in the total above-ground biomass were low (i.e. less than a half). This enables to conclude that there is a close relationship between the total above-ground biomass and that of potentially productive tillers already at the stage of stem elongation. Because of a low variability it is possible to use the proportion of potentially productive tillers in the total above-ground biomass for the estimation of a productive potential of the crop. This finding can be useful for more effective methods of canopy control based on spectral characteristics and on indirect estimation of above-ground biomass using the NDVI.

\subsection{Reproductive period}

Although the differentiation and abortion of vegetative tillers is still proceeding, the process of yield structure formation is practically terminated. Shoot system has no more the adaptation function, which is now provided by ear structures and reproductive organs. Adaptation proceeds by grain filling; the importance of physiological processes taking part 
in it is increasing. These are usually explained by the theory of source $x$ sink, which has been long applied in scientific papers oriented to yield formation in cereal crops. It is generally accepted that biomass of productive stems at anthesis correlates with the number of grains per $\mathrm{m}^{2}$, and the duration of leaf area correlates with the of 1000-grain weight.

The following stand parameters can be considered important during the reproductive period:

- number of productive shoots,

- canopy closure,

- total aboveground biomass,

- biomass of productive shoots,

- active green area, its duration and health status,

- resistance to lodging.

\subsection{Canopy spectral characteristic - NDVI}

The obtained results confirmed the certain possibility of NDVI application for the assessment of the condition of cereal stands. Higher values of NDVI indicated:

- a greater amount of biomass and its dry matter per $\mathrm{m}^{2}$ and higher values of LAI, above all in the period of stem elongation,

- a greater average weight of plants, a higher number of tillers per plant, and a higher number of plants per $\mathrm{m}^{2}$ within the stage of tillering,

- a greater average weight of tillers and a higher number of tillers per $\mathrm{m}^{2}$ at the beginning of stem elongation,

- a more intensive green colour of the stand, which indicated a better nutritional status of the stand as far as nitrogen supply was concerned.

At later phenological stages, these relationships between NDVI and productive traits of the stand were not so strong.

Similar values of NDVI may indicate either a greater amount of aboveground biomass with a deficit of nitrogen or a smaller amount of it in a good nutritional status. It is also difficult to decide whether the given amount of aboveground biomass was produced by a greater number of less tillering plants or, on the contrary, of a smaller number of plants with more tillers. The effect of canopy morphological (i.e. structural) and physiological characteristics on values of NDVI, therefore, requires further investigations.

Traits characterizing heterogeneity of the stand (i.e. CV of the weights of plants and tillers) correlated negatively with the NDVI. This finding may be important for the interpretation of NDVI values, above all in the period when the stand canopy is not fully developed, i.e. usually till the beginning of stem elongation $(\mathrm{BBCH} 31)$ when NDVI values are influenced by radiation reflected by plants and soil surface. In this period, the assessment of NDVI could be used to evaluate quality of stand establishment (i.e. of the uniformity of plant distribution).

In spite of a difficult interpretation of structural stand parameters the present level of knowledge enables to use NDVI in practice. A great advantage of NDVI is a possibility of a 
quick areal evaluation of heterogeneity of cereal canopy within the fields which can be used in precision agriculture.

\section{Appendix}

Correlations between NDVI and different canopy characteristic - tables 13,14,15 for winter wheat.

Correlations between NDVI and different canopy characteristic - tables 16, 17, 18 for spring barley.

\begin{tabular}{|c|c|c|c|c|c|c|c|c|c|c|}
\hline & Trait & $\mathrm{BBCH}$ & $\mathrm{n}-2$ & 2 & 3 & 4 & 5 & 6 & 7 & 8 \\
\hline \multirow{3}{*}{1} & \multirow{3}{*}{$\begin{array}{l}\text { Number of plants per } \\
\qquad \mathrm{m}^{2}\end{array}$} & 25 & 8 & 0.521 & 0.225 & 0.194 & 1 & & & 0.031 \\
\hline & & 31 & 8 & 0.606 & $0.714^{*}$ & 0.599 & 1 & $0.697^{*}$ & $0.663^{*}$ & 0.609 \\
\hline & & 37 & 2 & 0.211 & 0.378 & -0.001 & -0.074 & 0.913 & 0.297 & 0.436 \\
\hline \multirow{4}{*}{2} & \multirow{4}{*}{$\begin{array}{l}\text { Number of tillers per } \\
\mathrm{m}^{2}\end{array}$} & 25 & 8 & 1 & $0.692^{*}$ & $0.685^{*}$ & 1 & & & 0.553 \\
\hline & & 31 & 8 & 1 & $0.665^{*}$ & 0.446 & 1 & 0.596 & 0.422 & 0.702 \\
\hline & & 37 & 4 & 1 & $0.947^{* *}$ & $0.860^{*}$ & 0.665 & 0.223 & $0.888^{*}$ & 0.295 \\
\hline & & 65 & 8 & 1 & $0.979^{* *}$ & $0.923^{* *}$ & 0.485 & $0.835^{* *}$ & $0.942^{* *}$ & $0.739^{*}$ \\
\hline \multirow{4}{*}{3} & \multirow{4}{*}{$\begin{array}{l}\text { Weight of total above- } \\
\text { ground biomass } \\
\left(\mathrm{g} \cdot \mathrm{m}^{-2}\right)\end{array}$} & 25 & 8 & & 1 & $0.988^{* *}$ & 1 & & & $0.800^{* *}$ \\
\hline & & 31 & 8 & & 1 & $0.941^{* *}$ & 1 & 0.601 & $0.888^{* *}$ & $0.960^{* *}$ \\
\hline & & 37 & 4 & & 1 & $0.827^{*}$ & 0.532 & 0.245 & $0.866^{*}$ & 0.206 \\
\hline & & 65 & 8 & & 1 & $0.954^{* *}$ & 0.549 & $0.829^{* *}$ & $0.943^{* *}$ & $0.709^{*}$ \\
\hline \multirow{4}{*}{4} & \multirow{4}{*}{$\begin{array}{c}\text { Total dry matter } \\
\text { weight } \\
\left(\mathrm{g} \cdot \mathrm{m}^{-2}\right)\end{array}$} & 25 & 8 & & & 1 & -1 & & & $0.868^{* *}$ \\
\hline & & 31 & 8 & & & 1 & 1 & 0.518 & $0.937^{* *}$ & $0.834^{* *}$ \\
\hline & & 37 & 4 & & & 1 & $0.863^{*}$ & -0.134 & $0.879^{*}$ & 0.514 \\
\hline & & 65 & 8 & & & 1 & 0.628 & $0.884^{* *}$ & $0.952^{* *}$ & 0.595 \\
\hline \multirow{4}{*}{5} & \multirow{4}{*}{$\begin{array}{c}\text { LAI } \\
\left(\mathrm{m}^{-2} \cdot \mathrm{m}^{-2}\right)\end{array}$} & 25 & 0 & & & & 1 & & & -1 \\
\hline & & 31 & 0 & & & & 1 & 1 & 1 & \\
\hline & & 37 & 4 & & & & 1 & -0.377 & 0.660 & $0.824^{*}$ \\
\hline & & 65 & 10 & & & & 1 & 0.474 & 0.560 & 0.510 \\
\hline \multirow{4}{*}{6} & \multirow{4}{*}{$\begin{array}{l}\text { Number of productive } \\
\text { tillers per } \mathrm{m}^{2}\end{array}$} & 25 & 0 & & & & & 1 & & \\
\hline & & 31 & 8 & & & & & 1 & $0.707^{*}$ & 0.243 \\
\hline & & 37 & 4 & & & & & 1 & 0.345 & -0.391 \\
\hline & & 65 & 10 & & & & & 1 & $0.904^{* *}$ & 0.552 \\
\hline \multirow{4}{*}{7} & \multirow{4}{*}{$\begin{array}{l}\text { Weight of productive } \\
\text { tillers }\left(\mathrm{g} \cdot \mathrm{m}^{-2}\right)\end{array}$} & 25 & 0 & & & & & & 1 & \\
\hline & & 31 & 8 & & & & & & 1 & $0.714^{*}$ \\
\hline & & 37 & 4 & & & & & & 1 & 0.365 \\
\hline & & 65 & 10 & & & & & & 1 & $0.639^{*}$ \\
\hline \multirow{2}{*}{8} & \multirow{2}{*}{ NDVI } & $25 / 31$ & $7 / 6$ & & & & & & & $1 / 1$ \\
\hline & & $37 / 65$ & $4 / 10$ & & & & & & & $1 / 1$ \\
\hline
\end{tabular}

Table 13. Correlations between NDVI and morphological traits at the level of winter wheat stand ( ${ }^{*}$ statistically significant, ${ }^{* *}$ statistically highly significant) 


\begin{tabular}{|c|c|c|c|c|c|c|c|c|c|c|c|}
\hline & Trait & $\mathrm{BBCH}$ & $n-2$ & 2 & 3 & 4 & 5 & 6 & 7 & 8 & 9 \\
\hline \multirow{3}{*}{1} & \multirow{3}{*}{$\begin{array}{c}\text { Average plant } \\
\text { weight }(\mathrm{g})\end{array}$} & 25 & 8 & -0.606 & $0.727^{*}$ & $-0.738^{*}$ & 0.451 & & & & $0.804^{* *}$ \\
\hline & & 31 & 8 & -0.468 & 0.382 & 0.182 & $0.640^{*}$ & 0.047 & $0.631^{*}$ & -0.533 & 0.513 \\
\hline & & 37 & 2 & $-0.975^{*}$ & 0.934 & -0.814 & 0.616 & & $0.996^{* *}$ & -0.870 & 0.710 \\
\hline \multirow{3}{*}{2} & \multirow{3}{*}{$\begin{array}{l}\text { CV of plant } \\
\text { weight }(\%)\end{array}$} & 25 & 8 & 1 & $-0.869^{* *}$ & $0.886^{* *}$ & 0.301 & & & & -0.437 \\
\hline & & 31 & 8 & 1 & -0.015 & 0.201 & -0.479 & -0.464 & $-0.708^{*}$ & $0.658^{*}$ & $-0.977^{* *}$ \\
\hline & & 37 & 2 & 1 & -0.835 & 0.886 & -0.773 & & $-0.991^{* *}$ & 0.949 & -0.736 \\
\hline \multirow{3}{*}{3} & \multirow{3}{*}{$\begin{array}{l}\text { Average } \\
\text { number of } \\
\text { tillers per } \\
\text { plant } \\
\end{array}$} & 25 & 8 & & 1 & $-0.905^{* *}$ & -0.245 & & & & 0.590 \\
\hline & & 31 & 8 & & 1 & 0.603 & -0.438 & $-0.688^{*}$ & -0.313 & -0.568 & 0.088 \\
\hline & & 37 & 2 & & 1 & -0.582 & 0.297 & & 0.901 & -0.669 & 0.652 \\
\hline \multirow[b]{3}{*}{4} & \multirow{3}{*}{$\begin{array}{l}\mathrm{CV} \text { of the } \\
\text { average } \\
\text { number of } \\
\text { tillers per } \\
\text { plant }\end{array}$} & 25 & 8 & & & 1 & 0.143 & & & & -0.557 \\
\hline & & 31 & 8 & & & 1 & -0.344 & -0.197 & -0.297 & -0.069 & -0.258 \\
\hline & & 37 & 2 & & & 1 & -0.859 & & -0.839 & 0.827 & -0.388 \\
\hline \multirow{4}{*}{5} & \multirow{4}{*}{$\begin{array}{c}\text { Average tiller } \\
\text { weight }(\mathrm{g})\end{array}$} & 25 & 8 & & & & 1 & & & & 0.622 \\
\hline & & 31 & 8 & & & & 1 & 0.590 & $0.871^{* *}$ & -0.122 & 0.493 \\
\hline & & 37 & 4 & & & & 1 & & 0.570 & $-0.866^{*}$ & 0.048 \\
\hline & & 65 & 8 & & & & 1 & $-0.966^{*}$ & 0.400 & 0.120 & 0.288 \\
\hline \multirow{4}{*}{6} & \multirow{4}{*}{$\begin{array}{l}\mathrm{CV} \text { of the } \\
\text { weight of } \\
\text { tillers (\%) }\end{array}$} & 25 & 0 & & & & & 1 & & & \\
\hline & & 31 & 8 & & & & & 1 & 0.624 & 0.290 & 0.439 \\
\hline & & 37 & 0 & & & & & 1 & & & \\
\hline & & 65 & 2 & & & & & 1 & 0.468 & -0.522 & 0.851 \\
\hline \multirow{4}{*}{7} & \multirow{4}{*}{$\begin{array}{l}\text { Average } \\
\text { weight of a } \\
\text { productive } \\
\text { tiller (g) }\end{array}$} & 25 & 0 & & & & & & 1 & & \\
\hline & & 31 & 8 & & & & & & 1 & -0.331 & $0.746^{*}$ \\
\hline & & 37 & 4 & & & & & & 1 & $-0.866^{*}$ & 0.568 \\
\hline & & 65 & 10 & & & & & & 1 & $-0.753^{* *}$ & 0.491 \\
\hline \multirow{4}{*}{8} & \multirow{4}{*}{$\begin{array}{l}\mathrm{CV} \text { of the } \\
\text { weight of } \\
\text { productive } \\
\text { tillers (\%) }\end{array}$} & 25 & 0 & & & & & & & 1 & \\
\hline & & 31 & 8 & & & & & & & 1 & $-0.866^{* *}$ \\
\hline & & 37 & 4 & & & & & & & 1 & -0.384 \\
\hline & & 65 & 10 & & & & & & & 1 & -0.241 \\
\hline \multirow{4}{*}{9} & \multirow{4}{*}{ NDVI } & 25 & 7 & & & & & & & & 1 \\
\hline & & 31 & 6 & & & & & & & & 1 \\
\hline & & 37 & 4 & & & & & & & & 1 \\
\hline & & 65 & 10 & & & & & & & & 1 \\
\hline
\end{tabular}

Table 14. Correlations between NDVI and morphological traits under study at the level of individual plants and tillers of winter wheat ${ }^{*}$ statistically significant, ${ }^{* *}$ statistically highly significant) 


\begin{tabular}{|c|c|c|c|c|c|c|c|}
\hline & Trait & $\mathrm{BBCH}$ & $n-2$ & 2 & 3 & 4 & 5 \\
\hline \multirow{4}{*}{1} & \multirow{4}{*}{$\begin{array}{l}\text { Uptake of } \mathrm{N} \text { in above- } \\
\text { ground biomass (g) }\end{array}$} & 25 & 4 & & & & -0.465 \\
\hline & & 31 & 4 & $0.834^{*}$ & 0.649 & $0.860^{*}$ & $0.946^{* *}$ \\
\hline & & 37 & 4 & $0.944^{* *}$ & 0.532 & -0.128 & 0.506 \\
\hline & & 65 & 10 & $0.957^{* *}$ & 0.337 & 0.547 & $0.802^{* *}$ \\
\hline \multirow{3}{*}{2} & \multirow{3}{*}{$\begin{array}{l}\text { Uptake of } \mathrm{N} \text { in biomass of } \\
\text { productive tillers }(\mathrm{g})\end{array}$} & 31 & 8 & 1 & 0.561 & $0.879^{*}$ & $0.767^{*}$ \\
\hline & & 37 & 4 & 1 & 0.278 & -0.149 & 0.408 \\
\hline & & 65 & 8 & 1 & 0.307 & 0.527 & 0.546 \\
\hline \multirow{4}{*}{3} & \multirow{4}{*}{$\begin{array}{l}\text { Content of chlorophyll in } \\
\text { above-ground biomass }\end{array}$} & 25 & 4 & & 1 & & -0.749 \\
\hline & & 31 & 4 & & 1 & 0.722 & 0.781 \\
\hline & & 37 & 4 & & 1 & -0.511 & 0.670 \\
\hline & & 65 & 4 & & 1 & 0.760 & 0.682 \\
\hline \multirow{3}{*}{4} & \multirow{3}{*}{$\begin{array}{l}\text { Content of chlorophyll in } \\
\text { biomass of productive tillers }\end{array}$} & 31 & 4 & & & 1 & $0.889^{*}$ \\
\hline & & 37 & 4 & & & 1 & -0.486 \\
\hline & & 65 & 4 & & & 1 & $0.819^{*}$ \\
\hline \multirow{3}{*}{5} & & 31 & 6 & & & & 1 \\
\hline & NDVI & 37 & 4 & & & & 1 \\
\hline & & 65 & 10 & & & & 1 \\
\hline
\end{tabular}

Table 15. Correlations between NDVI and uptake of nitrogen and chlorophyll content in aboveground biomass of winter wheat $\left({ }^{*}\right.$ statistically significant, ${ }^{* *}$ statistically highly significant)

\begin{tabular}{|c|c|c|c|c|c|c|c|c|c|c|}
\hline & Trait & $\mathrm{BBCH}$ & $n-2$ & 2 & 3 & 4 & 5 & 6 & 7 & 8 \\
\hline \multirow{2}{*}{1} & \multirow{2}{*}{$\begin{array}{c}\text { Number of plants per } \\
\mathrm{m}^{2}\end{array}$} & 22 & 16 & $0.568^{*}$ & 0.324 & 0.377 & 0.514 & & & 0.233 \\
\hline & & 31 & 12 & $0.653^{*}$ & 0.540 & 0.452 & 0.285 & 0.264 & 0.405 & 0.167 \\
\hline \multirow{6}{*}{2} & \multirow{6}{*}{$\begin{array}{l}\text { Number of tillers per } \\
\mathrm{m}^{2}\end{array}$} & 22 & 16 & 1 & $0.692^{* *}$ & $0.715^{* *}$ & $0.961^{*}$ & & & 0.438 \\
\hline & & 31 & 12 & 1 & $0.891^{* *}$ & $0.783^{* *}$ & $0.827^{* *}$ & $0.736^{* *}$ & $0.845^{* *}$ & $0.609^{*}$ \\
\hline & & 37 & 4 & 1 & 0.058 & 0.106 & -0.509 & -0.121 & -0.040 & 0.216 \\
\hline & & 55 & 6 & 1 & $0.953^{* *}$ & $0.915^{* *}$ & 0.491 & $0.933^{* *}$ & $0.953^{* *}$ & $0.878^{* *}$ \\
\hline & & 65 & 8 & 1 & $0.930^{* *}$ & $0.853^{* *}$ & 0.632 & $0.862^{* *}$ & $0.905^{* *}$ & 0.701 \\
\hline & & 87 & 2 & 1 & 0.837 & 0.862 & 0.102 & & & 0.547 \\
\hline
\end{tabular}




\begin{tabular}{|c|c|c|c|c|c|c|c|c|c|c|}
\hline & Trait & $\mathrm{BBCH}$ & $\mathrm{n}-2$ & 2 & 3 & 4 & 5 & 6 & 7 & 8 \\
\hline \multirow{6}{*}{3} & \multirow{6}{*}{$\begin{array}{c}\text { Weight of total } \\
\text { above-ground biomass } \\
\left(\mathrm{g} \cdot \mathrm{m}^{-2}\right)\end{array}$} & 22 & 16 & & 1 & $0.979^{* *}$ & $0.966^{*}$ & & & $0.801^{* *}$ \\
\hline & & 31 & 11 & & 1 & $0.959^{* *}$ & $0.824^{* *}$ & $0.605^{*}$ & $0.979^{* *}$ & $0.793^{* *}$ \\
\hline & & 37 & 4 & & 1 & $0.992^{* *}$ & $0.994^{* *}$ & $0.946^{* *}$ & $0.993^{* *}$ & 0.783 \\
\hline & & 55 & 6 & & 1 & $0.934^{* *}$ & 0.490 & $0.889^{* *}$ & $0.979^{* *}$ & $0.898^{* *}$ \\
\hline & & 65 & 8 & & 1 & $0.870^{* *}$ & 0.641 & $0.903^{* *}$ & $0.992^{* *}$ & $0.836^{* *}$ \\
\hline & & 87 & 2 & & 1 & 0.858 & 0.662 & 0.893 & $0.981^{*}$ & 0.843 \\
\hline \multirow{6}{*}{4} & \multirow{6}{*}{$\begin{array}{c}\text { Total dry matter } \\
\text { weight } \\
\left(\mathrm{g} \cdot \mathrm{m}^{-2}\right)\end{array}$} & 22 & 16 & & & 1 & $0.989^{*}$ & & & $0.811^{* *}$ \\
\hline & & 31 & 11 & & & 1 & $0.697^{*}$ & 0.441 & $0.944^{* *}$ & $0.880^{* *}$ \\
\hline & & 37 & 4 & & & 1 & $0.974^{* *}$ & $0.913^{*}$ & $0.976^{* *}$ & $0.814^{*}$ \\
\hline & & 55 & 6 & & & 1 & 0.170 & $0.817^{*}$ & $0.893^{* *}$ & $0.973^{* *}$ \\
\hline & & 65 & 8 & & & 1 & 0.665 & $0.845^{* *}$ & $0.871^{* *}$ & $0.840^{* *}$ \\
\hline & & 87 & 2 & & & 1 & -0.231 & & & 0.709 \\
\hline \multirow{6}{*}{5} & \multirow{6}{*}{$\begin{array}{c}\text { LAI } \\
\left(\mathrm{m}^{2} \cdot \mathrm{m}^{-2}\right)\end{array}$} & 22 & 2 & & & & 1 & & & $0.920^{* *}$ \\
\hline & & 31 & 9 & & & & 1 & $0.719^{*}$ & $0.833^{* *}$ & 0.501 \\
\hline & & 37 & 3 & & & & 1 & $0.980^{* *}$ & $0.995^{* *}$ & 0.695 \\
\hline & & 55 & 6 & & & & 1 & 0.530 & 0.531 & 0.124 \\
\hline & & 65 & 6 & & & & 1 & 0.629 & 0.629 & 0.484 \\
\hline & & 87 & 14 & & & & 1 & & & 0.827 \\
\hline \multirow{4}{*}{6} & \multirow{4}{*}{$\begin{array}{l}\text { Number of productive } \\
\text { tillers per } \mathrm{m}^{2}\end{array}$} & 31 & 12 & & & & & 1 & 0.635 & 0.354 \\
\hline & & 37 & 4 & & & & & 1 & $0.974^{* *}$ & 0.643 \\
\hline & & 55 & 6 & & & & & 1 & $0.937^{* *}$ & $0.857^{* *}$ \\
\hline & & 65 & 8 & & & & & 1 & $0.942^{* *}$ & $0.857^{* *}$ \\
\hline \multirow{4}{*}{7} & \multirow{4}{*}{$\begin{array}{l}\text { Weight of productive } \\
\text { tillers }\left(\mathrm{g} \cdot \mathrm{m}^{-2}\right)\end{array}$} & 31 & 12 & & & & & & 1 & $0.840^{* *}$ \\
\hline & & 37 & 4 & & & & & & 1 & 0.745 \\
\hline & & 55 & 6 & & & & & & 1 & $0.886^{* *}$ \\
\hline & & 65 & 8 & & & & & & 1 & $0.853^{* *}$ \\
\hline \multirow{6}{*}{8} & \multirow{6}{*}{ NDVI } & 22 & 16 & & & & & & & 1 \\
\hline & & 31 & 11 & & & & & & & 1 \\
\hline & & 37 & 4 & & & & & & & 1 \\
\hline & & 55 & 6 & & & & & & & 1 \\
\hline & & 65 & 6 & & & & & & & 1 \\
\hline & & 87 & 4 & & & & & & & 1 \\
\hline
\end{tabular}

Table 16. Correlations between NDVI and morphological traits at the level of spring barley stand (* statistically significant, ${ }^{* *}$ statistically highly significant) 


\begin{tabular}{|c|c|c|c|c|c|c|c|c|c|c|c|}
\hline & Trait & $\mathrm{BBCH}$ & $n-2$ & 2 & 3 & 4 & 5 & 6 & 7 & 8 & 9 \\
\hline \multirow{2}{*}{1} & \multirow{2}{*}{$\begin{array}{c}\text { Average plant } \\
\text { weight }(\mathrm{g})\end{array}$} & 22 & 16 & -0.231 & $0.658^{* *}$ & -0.330 & 0.050 & & & & $0.696^{* *}$ \\
\hline & & 31 & 12 & 0.084 & $0.843^{* *}$ & -0.559 & $0.628^{*}$ & -0.056 & $0.617^{*}$ & -0.289 & $0.831^{* *}$ \\
\hline \multirow{2}{*}{2} & \multirow{2}{*}{$\begin{array}{l}\text { CV of plant } \\
\text { weight }(\%)\end{array}$} & 22 & 10 & 1 & -0.157 & $0.749^{* *}$ & -0.247 & & & & -0.382 \\
\hline & & 31 & 10 & 1 & 0.224 & 0.527 & -0.243 & 0.343 & -0.157 & 0.226 & -0.140 \\
\hline \multirow[b]{2}{*}{3} & \multirow{2}{*}{$\begin{array}{c}\text { Average } \\
\text { number of } \\
\text { tillers per } \\
\text { plant }\end{array}$} & 22 & 16 & & 1 & -0.323 & -0.287 & & & & 0.260 \\
\hline & & 31 & 12 & & 1 & -0.531 & 0.129 & 0.081 & 0.194 & 0.013 & $0.647^{*}$ \\
\hline \multirow[b]{2}{*}{4} & \multirow{2}{*}{$\begin{array}{l}\mathrm{CV} \text { of the } \\
\text { average } \\
\text { number of } \\
\text { tillers per } \\
\text { plant }\end{array}$} & 22 & 10 & & & 1 & -0.485 & & & & -0.360 \\
\hline & & 31 & 10 & & & 1 & -0.279 & 0.326 & -0.251 & 0.134 & -0.534 \\
\hline \multirow{6}{*}{5} & \multirow{6}{*}{$\begin{array}{c}\text { Average tiller } \\
\text { weight }(\mathrm{g})\end{array}$} & 22 & 16 & & & & 1 & & & & 0.207 \\
\hline & & 31 & 12 & & & & 1 & -0.204 & $0.874^{* *}$ & -0.528 & $0.626^{*}$ \\
\hline & & 37 & 4 & & & & 1 & -0.798 & $0.981^{* *}$ & 0.399 & 0.756 \\
\hline & & 55 & 6 & & & & 1 & 0.099 & $0.944^{* *}$ & 0.628 & $0.869^{* *}$ \\
\hline & & 65 & 8 & & & & 1 & 0.100 & $0.927^{* *}$ & 0.064 & $0.793^{*}$ \\
\hline & & 87 & 2 & & & & 1 & -0.566 & & & 0.064 \\
\hline \multirow{5}{*}{6} & \multirow{5}{*}{$\begin{array}{l}\mathrm{CV} \text { of the } \\
\text { weight of } \\
\text { tillers (\%) }\end{array}$} & 31 & 12 & & & & & 1 & 0.176 & $-0.062^{*}$ & 0.331 \\
\hline & & 37 & 4 & & & & & 1 & -0.698 & -0.505 & -0.311 \\
\hline & & 55 & 6 & & & & & 1 & 0.333 & 0.058 & 0.036 \\
\hline & & 65 & 8 & & & & & 1 & 0.240 & 0.150 & -0.376 \\
\hline & & 87 & 2 & & & & & 1 & & & 0.651 \\
\hline \multirow{4}{*}{7} & \multirow{4}{*}{$\begin{array}{c}\text { Average } \\
\text { weight of a } \\
\text { productive } \\
\text { tiller (g) }\end{array}$} & 31 & 12 & & & & & & 1 & $-0.760^{* *}$ & $0.811^{* *}$ \\
\hline & & 37 & 4 & & & & & & 1 & 0.232 & $0.821^{*}$ \\
\hline & & 55 & 6 & & & & & & 1 & 0.543 & $0.799^{*}$ \\
\hline & & 65 & 8 & & & & & & 1 & -0.239 & $0.715^{*}$ \\
\hline \multirow{4}{*}{8} & \multirow{4}{*}{$\begin{array}{l}\mathrm{CV} \text { of the } \\
\text { weight of } \\
\text { productive } \\
\text { tillers }(\%)\end{array}$} & 31 & 12 & & & & & & & 1 & -0.490 \\
\hline & & 37 & 4 & & & & & & & 1 & 0.112 \\
\hline & & 55 & 6 & & & & & & & 1 & 0.322 \\
\hline & & 65 & 8 & & & & & & & 1 & -0.134 \\
\hline \multirow{3}{*}{9} & \multirow{3}{*}{ NDVI } & $22 / 31$ & $16 / 11$ & & & & & & & & $1 / 1$ \\
\hline & & $37 / 55$ & $4 / 6$ & & & & & & & & $1 / 1$ \\
\hline & & $65 / 87$ & $6 / 4$ & & & & & & & & $1 / 1$ \\
\hline
\end{tabular}

Table 17. Correlations between NDVI and morphological traits at the level of individual plants and tillers of spring barley ( ${ }^{*}$ statistically significant, ${ }^{* *}$ statistically highly significant) 


\begin{tabular}{|c|c|c|c|c|c|c|c|}
\hline & Trait & $\mathrm{BBCH}$ & $n-2$ & 2 & 3 & 4 & 5 \\
\hline \multirow{5}{*}{1} & \multirow{5}{*}{$\begin{array}{l}\text { Content of } \mathrm{N} \text { in above- } \\
\text { ground biomass (g) }\end{array}$} & 22 & 10 & & 0.143 & & $0.852^{* *}$ \\
\hline & & 31 & 12 & $0.969^{* *}$ & $0.461^{* *}$ & $0.921^{* *}$ & $0.899^{* *}$ \\
\hline & & 55 & 6 & $0.970^{* *}$ & 0.235 & 0.659 & $0.751^{*}$ \\
\hline & & 65 & 8 & $0.995^{* *}$ & 0.800 & $0.983^{* *}$ & $0.918^{* *}$ \\
\hline & & 87 & 2 & $0.960^{*}$ & & & 0.725 \\
\hline \multirow{4}{*}{2} & \multirow{4}{*}{$\begin{array}{l}\text { Content of } \mathrm{N} \text { in biomass of } \\
\text { productive tillers }(\mathrm{g})\end{array}$} & 31 & 11 & 1 & $0.637^{*}$ & $0.969^{* *}$ & $0.889^{* *}$ \\
\hline & & 37 & 4 & 1 & & & 0.739 \\
\hline & & 55 & 6 & 1 & 0.209 & $0.733^{*}$ & $0.799^{*}$ \\
\hline & & 65 & 8 & 1 & 0.780 & $0.980^{*}$ & $0.829^{*}$ \\
\hline \multirow{4}{*}{3} & \multirow{4}{*}{$\begin{array}{l}\text { Content of chlorophyll in } \\
\text { above-ground biomass }\end{array}$} & 22 & 10 & & 1 & & 0.047 \\
\hline & & 31 & 10 & & 1 & $0.657^{*}$ & 0.440 \\
\hline & & 55 & 6 & & 1 & 0.645 & 0.370 \\
\hline & & 65 & 2 & & 1 & 0.889 & 0.969 \\
\hline \multirow{3}{*}{4} & \multirow{3}{*}{$\begin{array}{l}\text { Content of chlorophyll in } \\
\text { biomass of productive tillers }\end{array}$} & 31 & 9 & & & 1 & $0.925^{* *}$ \\
\hline & & 55 & 6 & & & 1 & $0.912^{* *}$ \\
\hline & & 65 & 2 & & & 1 & $0.974^{* *}$ \\
\hline \multirow{3}{*}{5} & \multirow{3}{*}{ NDVI } & $22 / 31$ & $16 / 11$ & & & & $1 / 1$ \\
\hline & & $37 / 55$ & $4 / 6$ & & & & $1 / 1$ \\
\hline & & $65 / 87$ & $6 / 4$ & & & & $1 / 1$ \\
\hline
\end{tabular}

Table 18. Correlations existing between NDVI and physiological traits under study ( ${ }^{*}$ statistically significant, ${ }^{* *}$ statistically highly significant)

\section{Author details}

Jan Křen, Tamara Dryšlová, Lubomír Neudert and Vojtěch Lukas

Department of Agrosystems and Bioclimatology, Faculty of Agronomy, Mendel University in Brno, Brno, Czech Republic

\section{Acknowledgement}

This study was supported by the Ministry of Agriculture of the Czech Republic, projects $\mathrm{N}^{\circ}$ s: QI111A133 and QJ1210008.

\section{References}

[1] Masle-Meynard J, Sebillotte M (1981) Etude de l'hétérogénéité d'un peuplement de blé d'hiver. I. Notion de structure du peuplement (Study on the heterogeneity of a winterwheat stand. 1. Notion of stand structure). Agronomie 1(3):207-215.

[2] Masle-Meynard J, Sebillotte M (1981) Etude de l'hétérogénéité d'un peuplement de blé d'hiver. II. Origine des différentes categories d'individus du peuplement: éléments de 
description de se structure. (Study on the heterogeneity of a winter-wheat stand. 2. Study on the different sorts of individuals of the stand - factors allowing the description of its structure). Agronomie 1(3):216-224.

[3] Porter J. R (1984) A model of canopy development in winter wheat. Journal of agricultural Science 102:383-392.

[4] Křen J (1990) Autoregulace a zákonitosti populační biologie rostlin v porostu pšenice (Autoregulation and the regulatories of plant population biology in the wheat stand). Rostlinná Výroba 36 (8):839-845.

[5] Křen J (1990) Rozdíly mezi rostlinami a stébly v porostu pšenice (Differences between the plants and stems in stand of winter wheat). Rostlinná výroba 36 (11):1121-1127.

[6] Křen J (1990) Změny variability rostlin a stébel v porostu pšenice (The changes in variability of plants and shoots in the wheat stand). Rostlinná výroba 36 (12):1251-1259.

[7] Kren J, Smoldas R, Lukas V, Misa P (2007) Within-crop variability affecting variable N application to winter wheat. 6th European Conference on Precision Agriculture (6ECPA), 3-6 June 2007, Skiathos, Greece, Wageningen Academic Publisher, pp. 697703.

[8] Muravjev S.A (1973) Stebleotbor v zlakovom fitocenoze (Stem selection in the cereal phytocenosys). Riga, Zinatne.

[9] Heuser W (1927/28) Die Ertragsanalyse von Getreide-züchtungen (Yield analyses in cereals breeding). Pflanzenbau 4, 6.3:353-357.

[10] Hunt R (1978) Demography versus plant growth analysis. New Phytologist 80:269-272.

[11] Petr J, Hnilica P, Hradecká D (1983) Studium optimální úrovně výnosových prvků a modelování tvorby výnosu (Optimum level of yield components research and modelling of yield formation). [Research report] Praha, VŠZ.

[12] Petr J et al (1983) Intenzívní obilnářství (Intensive grain production). SZN Praha, 377 pp.

[13] Watkinson A.R, White J (1985) Some life history consequences of modular constructions in plants. Philosophical Transactions of the Royal Society (London), B 313, pp. 31-51.

[14] White J (1979) The plant as a metapopulation. Annual Review of Ecology and Systematics 10:109-145.

[15] Porter J.R (1983) A modular approach to analysis of plant growth. I. Theory and principles. New Phytologist 94:183-190.

[16] Porter J.R (1983) A modular approach to analysis of plant growth. II. Methods and results. New Phytologist 94:191-200.

[17] De Wit C.T (1960) On competition. Versl. Landbanka-Onderz. 66:1-82.

[18] Koyama H, Kira T (1956) Intraspecific competition among higher plants. VIII. Frequency distribution of individual plant weight as affected by the interaction between plants. J. Inst. Polytechn. Osaka Univ. D 7:73-94.

[19] Malet P (1979) Liaison statistique entre le development et la croissance chez les plantes: application d'un modele simplific a l'analyse de la croissance (Statistical relationship 
between development and growth of plants: application of simplified model to growth analyses). Annales Agronomiques 30 (5) :415-430.

[20] Flowers M, Weisz R, Heiniger R (2001) Remote sensing of winter wheat tiller density for early nitrogen application decisions. Agronomy Journal 93:783-789.

[21] Flowers M, Weisz R, Heiniger R, Tarleton B, Meijer A (2003) Field validation of a remote sensing technique for early nitrogen application decisions in wheat. Agronomy Journal 95: 95-167.

[22] Phillips S.B, Keahey D.A, Warren J.G, Mullins G.L (2004) Estimating winter wheat tiller density using spectral reflectance sensor for early-spring, variable-rate nitrogen applications. Agronomy Journal 96:591-600.

[23] Reyniers M, Vrindts E, De Baerdemaeker J (2006) Comparison of an aerial-based system and an on the ground continuous measuring device to predict yield of winter wheat. European Journal of Agronomy 24:87-94.

[24] Rawson H.M (1971) Tillering patterns in wheat with special reference to the shoot at the colleoptille node. Austral. J. biol. Sci., 24: 829-841.

[25] Baker C. K, Gallagher J.N (1983) The development of winter wheat in the field. I. Relation between apical development and plant morphology within and between seasons. J. agric. Sci., Camb., 101: 327-335.

[26] Křen J. (1987) Výzkum variability odnožování a tvorby stébel u ozimé pšenice [Research of tillering and stalk formation variability of winter wheat]. Academic dissertation, Oseva - Cereal Research Institute Kroměříž, 134 s.

[27] Klepper B, Rickman R.W, Peterson C.M (1982) Quantitative characterization of vegetative development in small cereal-grains. Agron. J., 24: 789-792.

[28] Kirby E.J.M, Appleyard M, Fellowes G (1985) Effect of sowing date and variety on main shoot leaf emergence and number of leaves of barley and wheat. Agronomie, 5: 117-126.

[29] Křen J (1991) Využití poznatků o variabilitě rostlin a stébel v porostu pšenice. [The use of knowledge in variability of plants and stems in the wheat stand]. Rostlinná výroba 37 (4):297-305.

[30] Křen J, Souček A (1990) Jak posuzovat strukturu porostu pšenice. [How to assess wheat stand structure]. Úroda 38 (1):13-15.

[31] Rawson H.M, Evans L.T (1971) The contribution of stem reserves to grain development in a range of wheat cultivars of different height. Aust. J. agric. Res. 22:851-863.

[32] Křen J, Vlach M (1984) Některé zákonitosti tvorby výnosu stébel ozimé pšenice (Regulatories of stem yield formation in winter wheat). Rostlinná Výroba 30:95-102.

[33] Fischer R.A, Stockman Y.M (1980) Kernel number per spike in wheat (Triticum aestivum L.): responses to preanthesis shading. Aust. J. Plant Physiol. 7:169-180.

[34] Diekmann F, Fischbeck G (2005) Differences in wheat cultivar response to N supply. I: Differences in grain yield formation. Journal of Agronomy and Crop Science 191:351361. 
[35] Ugarte C, Calerdini D.F, Slafer G.A (2007) Grain weight and grain number responsiveness to pre-anthesis temperature in wheat, barley and triticale. Field Crops Research 100:240-248.

[36] Bancal P (2008) Positive contribution of stem growth to grain number per spike in wheat. Field Crops Research 105:27-39.

[37] Borras L, Slafer G.A, Otegui M.E (2004) Seed dry weight response to source-sink manipulations in wheat, maize and soybean: a quantitative reappraisal. Field Crops Research 86:131-146.

[38] Barbottin A, Lecomte C, Bouchard C, Jeuffroy M.H (2005) Nitrogen remobilization during grain filling in wheat: Genotypic and environmental effects. Crop Science 45:1141-1150.

[39] Gooding M.J, Gregory P.J, Ford K.E, Ruske R.E (2007) Recovery of nitrogen from different sources following applications to winter wheat at and after anthesis. Field Crops Research 100:143-154.

[40] Ehdaie B, Alloush G.A, Waines J.G (2008) Genotypic variation in linear rate of grain growth and contribution of stem reserves to grain yield in wheat. Field Crops Research 106:34-43.

[41] Kren J, van Keulen H, Grashoff C (1992) Grain growth in oats: experimentation and modeling. Research report, Centre for Agrobiological Research (CABO-DLO), Wageningen, The Netherlands, October, 132 pp.

[42] Kren J (1996) Possibilities of using modular growth and plant hierarchical structure to evaluate resource use in cereal growing. 4th Congress of the European Society for Agronomy, 7-11 July, Veldhoven - Wageningen, The Netherlands, Book of Abstracts, II: 560-561.

[43] Kira T, Ogawa H, Shinozaki K (1953) Intraspecific competition among higher plants. I. Competition - density - yield interrelatioships in regularly disperse populations. J. Inst. Polytech., Osaka Univ., D 4: 1-16.

[44] Darwinkel A (1978) Patterns of tillering and grain production of winter wheat at a wide range of plant densities. Neth. J. agric. Sci., 26: 383-398.

[45] Drezner W (1984) Zdolnost krzewienia sie pszenicy ozimej zwyczajnej jako cynik plonotworczy oraz element kszaltowania struktury plonu [Tillering ability of winter wheat as an indicator of yield formation and the component of yield structure]. Monograph, D 203.

[46] Slavíková J (1986) Ekologie rostlin [Plant ecology]. SNP, Praha, 366 s.

[47] Vlach M, Křen J (1984) Organizace porostu ozimé pšenice v závislosti na počtu rostlin na jednotce plochy [Organization of winter wheat stand in relation to number of plantes per unit of area]. Rostlinná výroba, 30: 287-294.

[48] Gustafssson A, Dormling I, Ekman G (1982) Barley and wheat under controlled climatic conditions: a model experiment of vigour and variability. Hereditas, 96: 1-11.

[49] Křen J (1993) Zásady zakládání porostů ozimé pšenice [Principles of winter wheat stand establishment]. Obilnářské listy, 1: 10-11. 
[50] Křen, J., Benada, J. 1990. Možnosti snižování výsevků obilnin [Possibilities of reducing seeding amount of cereals]. Úroda, 38: 343-345.

[51] Klepper B, Rickman R.W, Belford R.K (1983) Leaf and tiller identification on wheat plants. Crop Science, 23: 1002-1004.

[52] Harper J.L (1977) Population biology of plants. Academic press, London - New York San Francisco.

[53] Hammen V.C (2001) On-line sensing of cereal crop biomass. Dissertation, Humboldt Universität Berlin, pp. 171 [On-line] (http://edoc.hu-berlin.de/dissertationen/hammen-volker-carsten-2001-07-17)

[54] Scotford I.M, Miller P.CH (2004) Estimating tiller density and leaf area index of winter wheat using spectral reflectance and ultrasonic sensing techniques. Biosystems engineering 89:395-408.

[55] Aggarwal P.K, Fischer R.A, Lipoon S.P (1990) Source sink relations and effects of postanthesis canopy defoliation in wheat at low latitudes. J. Agric. Sci. 114:93-99.

[56] Arakawa A, Nakagawa H, Horie T (1999) Analysis of grain filling in two-rowed barley based on sink source relation. Japanese Journal of Crop Science 68:561-569.

[57] Sinclair T.R, Jamieson P.D (2008) Yield and grain number of wheat: A correlation or causal relationship? Authors' response to "The importance of grain or kernel number in wheat: A reply to Sinclair and Jamieson" by R.A. Fischer. 2008. Field Crops Research 105:22-26.

[58] Fischer R.A (2008) The importance of grain or kernel number in wheat: A reply to Sinclair and Jamieson. Field Crops Research 105:15-21.

[59] Calera A, Gonzalez-Piqueras J, Melia J (2004) Monitoring barley and corn growth from remote sensing data at field scale. International Journal of Remote Sensing 25:97-109.

[60] Freeman K.W, Raun W.R, Johnson G.V, Mullen R.W, Stone M.L, Solie J.B (2003) Lateseason prediction of wheat grain yield and grain protein. Communications in Soil Science and Plant Analysis 34:1837-1852.

[61] Aparicio N, Villegas D, Casadesus J, Araus J.L, Royo C (2000) Spectral vegetation indices as nondestructive tools for determining durum wheat yield. Agronomy Journal 92:83-91.

[62] Fetch T.G. Steffenson, B.J. Pederson, V.D (2004) Predicting agronomic performance of barley using canopy reflectance data. Canadian Journal of Plant Science 84:1-9.

[63] Zhao C.J, Liu L.Y, Wang J.H, Huang W.J, Song X.Y, Li C.J (2005) Predicting grain protein content of winter wheat using remote sensing data based on nitrogen status and water stress. International Journal of Applied Earth Observation and Geoinformation 7:1-9.

[64] Jorgensen R.N, Christensen L.K, Bro R (2007) Spectral reflectance at sub-leaf scale including the spatial distribution discriminating NPK stress characteristics in barley using multiway partial least squares regression. International Journal of Remote Sensing 28:943-962. 
[65] Zhang, J.H, Wang K, Bailey J.S, Wang R.C (2006) Predicting nitrogen status of rice using multispectral data at canopy scale. Pedosphere 16:108-117.

[66] Alvaro F, Del Moral L.F.G, Royo C (2007) Usefulness of remote sensing for the assessment of growth traits in individual cereal plants grown in the field. International Journal of Remote Sensing 28:2497-2512.

[67] Lorenzen B, Jensen A (1991) Spectral properties of a barley canopy in relation to the spectral properties of single leaves and the soil. Remote Sensing of Environment 37:2334.

[68] Behrens T, Müller J, Diepenbrock W (2006) Utilization of canopy reflectance to predict properties of oilseed rape (Brassica napus L.) and barley (Hordeum vulgare L.) during ontogenesis. European Journal of Agronomy 25:345-355. 